Kimmo Aronsuu1, 2, Risto Vikström³, Timo J. Marjomäki1, Kim Wennman², Jukka Pakkala3 , Eero Mäenpää3, Jukka Tuohino², Juha Sarell ${ }^{3}$ \& Esa 0jutkangas ${ }^{3}$

1)University of Jyväskylä, Department of Biological and Environmental Science, PO BOX 3540014 University of Jyväskylä, Finland, ${ }^{2)}$ Centre for Economic Development, Transport and the Environment for North Ostrobothnia, Oulu, Finland, ${ }^{3)}$ Centre for Economic Development, Transport and the Environment for South Ostrobothnia, Kokkola, Finland

\title{
Rehabilitation of two northern river lamprey (Lampetra fluviatilis) populations impacted by various anthropogenic pressures - lessons learnt in the past three decades
}

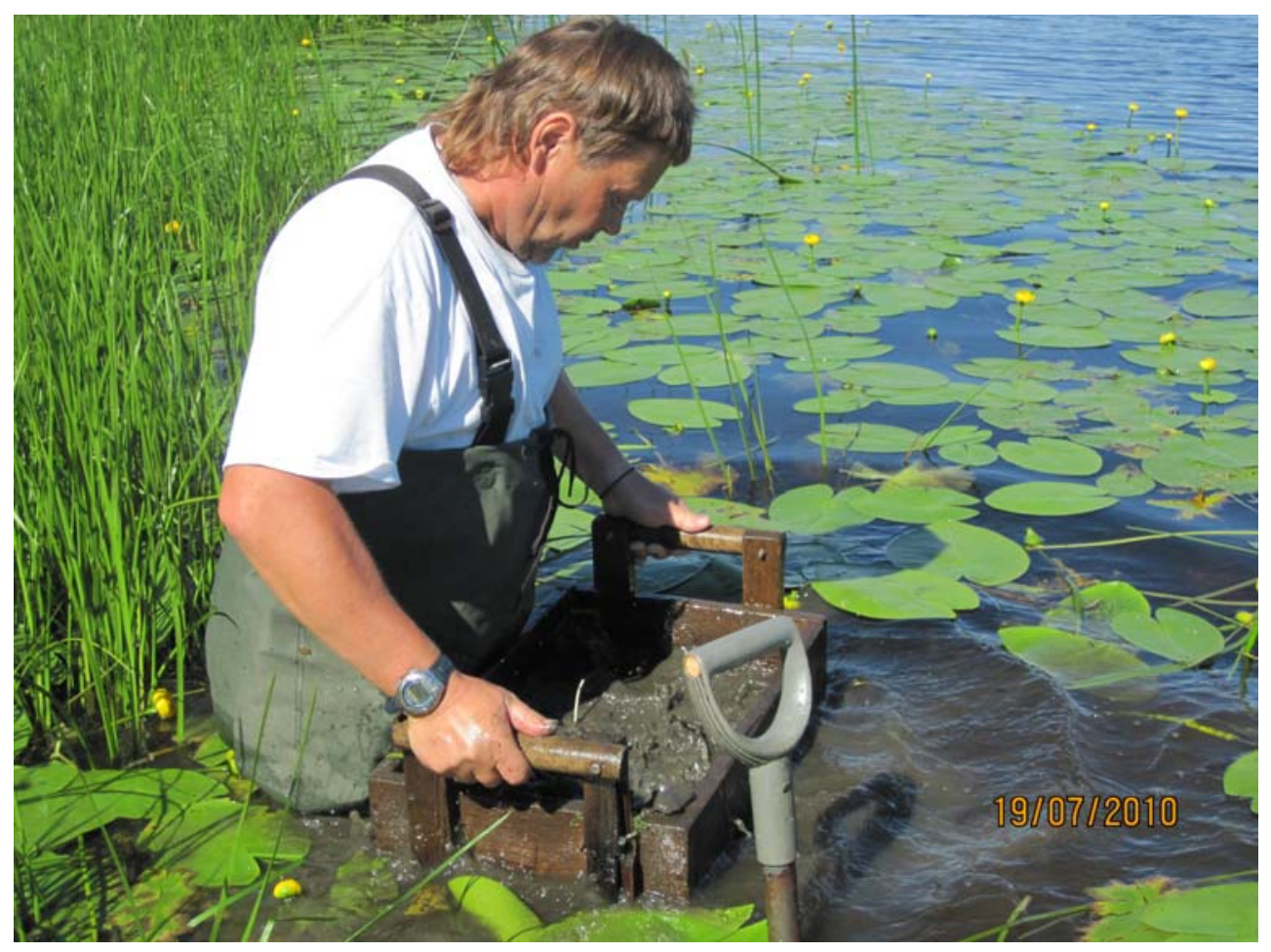


Jyväskylän yliopiston bio- ja ympäristötieteiden laitoksen tiedonantoja / Proceedings of the Department of Biological and Environmental Science, University of Jyväskylä

Toimittaja/Editor: Timo J. Marjomäki

Kansikuva/Cover photo: Kim Wennman

ISSN 2669-8986

ISBN 978-951-39-7801-3 (PDF)

Julkaisun pysyvä osoite / Permanent link to this publication:

http://urn.fi/URN:ISBN:978-951-39-7801-3

Jyväskylän yliopisto 2019 


\section{ABSTRACT}

Aronsuu, Kimmo, Vikström, Risto, Marjomäki, Timo J., Wennman, Kim, Pakkala, Jukka, Mäenpää, Eero, Tuohino, Jukka, Sarell, Juha \& Ojutkangas, Esa

Rehabilitation of two northern river lamprey (Lampetra fluviatilis) populations impacted by various anthropogenic pressures - lessons learnt in the past three decades

Jyväskylä: University of Jyväskylä, 2019, 52 p. + 2 appendices.

Proceedings of the department of biological and environmental science, University of Jyväskylä $2 / 2019$.

ISSN 2669-8986

ISBN 978-951-39-7801-3 (PDF)

The pioneering work done during the past three decades in the regulated Rivers Perhonjoki and Kalajoki, Finland, to study and rehabilitate river lamprey populations is presented. The effects of various anthropogenic activities and rehabilitation measures are evaluated based on habitat surveys and long-term monitoring of larval densities, numbers of adults migrating upstream and of transformers migrating downstream. Telemetric tracking and tagging experiments were used to determine the efficacy of fishways. Lamprey populations in both rivers decreased in the 1980s and 1990s. This was linked to obstructed upstream migration of adults and deterioration of habitats for different life stages due to various regulation measures and hydropeaking. In the River Perhonjoki, 571000 adult lampreys were translocated above the migration barriers in 1981-2010 and 247 million sub-yearling larvae were stocked in 1997-2010 of regulation. Furthermore, attempts were made to restore key habitats in various river sections, hydropeaking was mitigated and a fishway complex was constructed. Despite these mitigation measures, the river lamprey population has not recovered. In the River Kalajoki, a fish ramp was constructed to enhance migration over a weir and lampreys passed through it effectively. Further, fast-flowing areas were restored with lamprey-specific methods. After restoration the densities of both sub-yearling and older larvae increased, but despite the mitigation measures, larval densities in the river section just below the hydroelectric power plant remained at a low level. Possible mechanisms by which different anthropogenic activities affect different life stages of river lamprey and possible reasons for inefficacy or efficacy of rehabilitation measures are discussed.

Keywords: Dredging; erosion; habitat management; hydropower recovery; fish; river. 


\section{TIIVISTELMÄ}

Aronsuu, Kimmo, Vikström, Risto, Marjomäki, Timo J., Wennman, Kim, Pakkala, Jukka, Mäenpää, Eero, Tuohino, Jukka, Sarell, Juha \& Ojutkangas, Esa

Kahden ihmistoiminnasta kärsineen nahkiaispopulaation (Lampetra fluviatilis) ennallistaminen - kokemukset kolmen vuosikymmenen toimenpiteistä Jyväskylä: Jyväskylän yliopisto, 2019, 52 s. ja 2 liitettä.

Jyväskylän yliopiston bio- ja ympäristötieteiden laitoksen tiedonantoja 2/2019

ISSN 2669-8986

ISBN 978-951-39-7801-3 (PDF)

Tässä artikkelissa kuvataan Perhonjoen ja Kalajoen nahkiaispopulaatioita koskevat tutkimukset ja kompensaatiotoimenpiteet kolmen vuosikymmenen ajalta sekä pohditaan saatujen kokemusten valossa mahdollisia syitä toimenpiteiden tehottomuuteen tai tehokkuuteen. Ihmistoiminnan haittavaikutuksia ja kompensaatiotoimien tuloksellisuutta arvioitiin elinympäristökartoitusten ja toukkatiheyksien pitkän aikavälin seurannan, jokeen kutemaan nousevien aikuisten nahkiaisten määrän ja vaelluspoikasten määrän perusteella. Telemetriaseurantaa ja merkintäkokeita käytettiin kalateiden toimivuuden arvioimiseen. Kummankin joen nahkiaispopulaatio pieneni 1980luvulla ja 1990-luvulla. Tämä johtui sekä aikuisten nahkiaisten kutuvaelluksen estymisestä että vesirakentamisen ja lyhytaikaissäännöstelyn aiheuttamasta elinympäristöjen heikkenemisestä. Perhonjoella siirrettiin 571000 aikuista nahkiaista vaellusesteiden yläpuolelle jaksolla 1981-2010 ja istutettiin 247 miljoonaa muutaman viikon ikäistä toukkaa jaksolla 1997-2010. Lisäksi kunnostettiin tärkeimpiä nahkiaisten elinympäristöjä joen eri osissa, lievennettiin lyhytaikaissäännöstelyä ja rakennettiin kalatiekompleksi. Näistä kompensaatiotoimista huolimatta joen nahkiaispopulaatio taantui. Kalajoella rakennettiin pohjapatoon kalaporras, joka mahdollisti aikuisten nahkiaisten kutunousun. Lisäksi virta-alueet kunnostettiin nahkiaisen elintavat huomioivin menetelmin. Kunnostusten jälkeen sekä yksivuotiaiden että vanhempien nahkiaistoukkien tiheys kasvoi, mutta toimenpiteistä huolimatta toukkatiheydet pysyivät pieninä voimalaitoksen alapuolella sijaitsevalla jokiosuudella. Ympäristöä muuttavien toimenpiteiden haittojen ja niitä kompensoivien toimenpiteiden riittävyyden arviointiin sisältyy aina epävarmuutta. Nämä tutkimukset osoittivat, että epävarmuus on erityisen suurta, kun arvioinnin kohteena on laji, jolla on monimutkainen, huonosti tunnettu elinkierto ja aiempi tieto ihmistoiminnan haitoista ja kompensaatiotoimenpiteiden toimivuudesta on hyvin vähäistä.

Hakusanat: elinympäristö; istutus; kalatie; kunnostus; lyhytaikaissäännöstely; nahkiainen; vesirakentaminen. 


\section{CONTENTS}

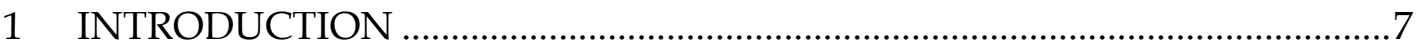

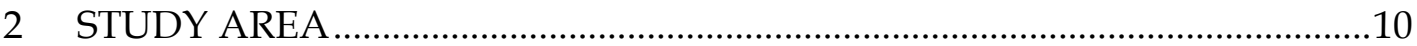

3 METHODS USED FOR MONITORING CHANGES IN LAMPREY POPULATIONS AND LARVAL HABITATS..................................13

3.1 The number of upstream-migrating adults, fishing mortality and escapement...............................................................................................13

3.2 Densities of larvae older than one year ....................................................16

3.3 Abundance of sub-yearling larvae.............................................................17

3.4 Downstream migration of transformers ……………………………….......17

3.5 Success of upstream-migrating adult lampreys at passing fishways .....19

3.6 The quantity and quality of larval habitats...................................................2

4 IMPACT OF ANTHROPOGENIC PRESSURES AND REHABILITATION MEASURES ON RIVER LAMPREY POPULATIONS ...22

4.1 The River Perhonjoki................................................................................22

4.1.1 Sections below the Kaitfors HPP (P1 and P2) ...............................22

4.1.2 The number of upstream-migrating adults ....................................2.

4.1.3 Sections between the Kaitfors and Pirttikoski HPPs (P3-P6) .......28

4.1.4 Section above the Pirttikoski HPP (P7)...............................................31

4.1.5 The River Ullavanjoki tributary ........................................................31

4.1.6 Transformers emigrating from above the Kaitfors HPP..................33

4.1.7 Enhancing passage over the Kaitfors dam.........................................33

4.2 The River Kalajoki .......................................................................................

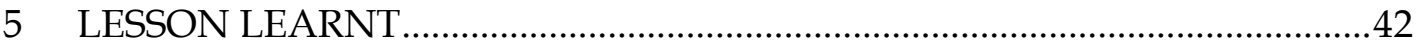

5.1 Translocations …………………………………………………….....42

5.2 Stocking of sub-yearling larvae ……………………………………….....4

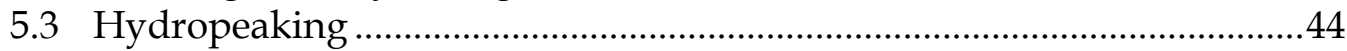

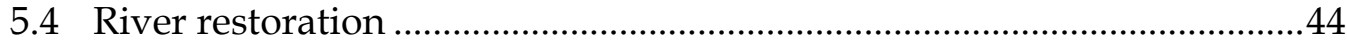

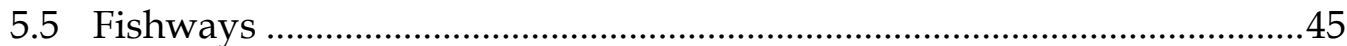

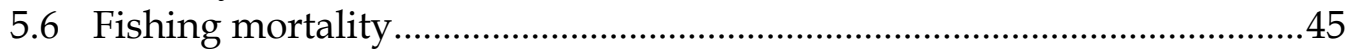

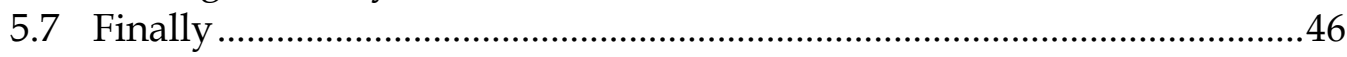

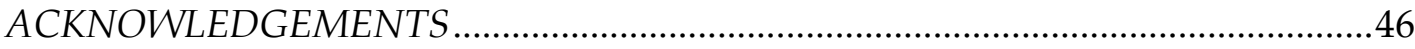

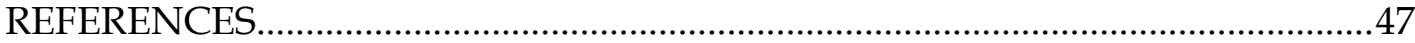

Appendix $1 \& 2$ 


\section{INTRODUCTION}

Populations of river lamprey (Lampetra fluviatilis), like those of many other lamprey species in the northern hemisphere, have declined due to anthropogenic activities (e.g. Ojutkangas et al. 1995, Renaud 1997, Close et al. 2002, Maitland 2003, Mateus et al. 2012). River lamprey is listed under Annex II of the European Commission Habitats directive (92/43/EEC) stipulating that the member states should maintain or restore habitats and species in a condition that ensures their favourable conservation status in the community. Furthermore, river lamprey receives conservation protection in Europe through the Bern Convention (82/72/EEC).

The reduction of river lamprey populations has been associated with dams preventing upstream migration of adults (Ojutkangas et al.1995, Lucas et al. 2009, Mateus et al. 2012, Foulds and Lucas 2013), deterioration of habitats for different life stages due to various river regulation measures such as impoundment, hydropeaking, dredging and embankments (Ojutkangas et al. 1995, Maitland 2003, Jang and Lucas 2005, Lucas et al. 2009), overfishing (Tuunainen et al. 1980, Masters et al. 2006, Foulds and Lucas 2014) and deteriorated water quality (Tuunainen et al. 1980, Myllynen et al. 1997, Mäenpää et al. 2001). During each life stage, lampreys are vulnerable to various human-induced changes in the environment. However, the actual mechanisms by which different anthropogenic pressures affect different lamprey life stages are not well understood.

Adult river lamprey migrate into rivers mainly in autumn and physical barriers like dams, weirs and artificial lighting may prevent or delay their migration to potential wintering and spawning sites (Lucas et al. 2009, Foulds and Lucas 2013, Aronsuu et al. 2015). Especially in the rivers flowing into the Bothnian Bay of the Baltic Sea, lampreys in the lowermost rapids close to the river mouth may be exposed to intensive fishing, inducing mortality exceeding 50 \% (Tuunainen et al. 1980, Valtonen 1980, Sjöberg 2011). In boreal regions, adult river lampreys winter in fast flowing areas, where refuge, like boulders, is available (Aronsuu et al. 2015). Lampreys in boreal rivers winter for 6 to 8 months, fasting in an energy saving hypometabolic state during the winter months (Gamber and Savina 2000). Knowledge regarding adult wintering is scarce, but it is probable that human-induced changes in hydromorphology and ice conditions are harmful for lampreys, as for various other fish species (Weber et al. 2013). In the spring, lampreys spawn in swift-running water on a substratum consisting of gravel that is 
sometimes mixed with sand and cobbles (Jang and Lucas 2005, Nika and Virbickas 2010). The decreased amount of suitable spawning habitat, as a result of anthropogenic impacts, has been regarded as a limiting factor for lamprey populations (Ojutkangas et al. 1995, Lucas et al. 2009), but Silva et al. (2015) have suggested that river lamprey egg development does not require as stringent conditions as for salmonid fish. Furthermore, Aronsuu and Tertsunen (2015) have recently shown that river lampreys may use a wide variety of gravel sizes for spawning. However, it is possible that the sieved, coarse gravel used so far for gravel augmentation in many restoration projects may not be optimal for river lamprey (see Smith and Marsden 2009, Aronsuu and Tertsunen 2015). Lamprey eggs hatch 11-12 days after fertilisation at a temperature of $12-15^{\circ} \mathrm{C}$ (Hardisty 2006). Lack of fine material in gravel may increase egg mortality (Smith and Marsden 2009), but on the other hand the mortality of eggs that drift to soft sediments may be high (Silva et al. 2015). Immediately after hatching at a length of $4 \mathrm{~mm}$, river lamprey are motionless and incapable of burrowing, but after 10 to 20 days at a length of 7-8 mm their ability to burrow commences and at that stage they likely need fine material to construct a burrow (Aronsuu and Virkkala 2014). During their first summer, larvae drift to soft-bottomed, slow-flowing river sections, where they live burrowed in the sediment for three to six years moving gradually downstream (Potter 1980). Habitat requirements of larval lampreys change while they grow (Beamish and Jebbink 1994, Almeida and Quintella 2002, Sugiyama and Goto 2002, Smith et al. 2011, Aronsuu and Virkkala 2014): subyearlings prefer very fine sand, but older larvae coarser sediments. Lamprey larvae reject clay bottoms (Smith et al. 2011, Aronsuu and Virkkala 2014), gravel and coarse sand (Lee 1989, Smith et al. 2011). In clay bottoms, larvae are exposed to predation (Smith et al. 2012). Also, the burrowing depth increases as a larva grows (Hardisty and Potter 1971) and large lampreys need deeper soft substratum than smaller ones (Sugiyama and Goto 2002). Dredging and erosion, for instance, may deteriorate both the quantity and quality of larval habitats (Ojutkangas et al. 1995, Renaud 1997, Maitland 2003). After metamorphosis, young adults (transformers) migrate to the sea. There are relatively few data available concerning the human impact on their emigration success, but it has been suggested that passage through turbines has only a minor impact on them (Moursund 2003, Bracken and Lucas 2013).

In the Rivers Perhonjoki and Kalajoki, the state of Finland was responsible for massive regulation measures started in the 1960s and lasting until the 1990s. As river lamprey was a species of considerable commercial importance in these rivers, the Environmental Court ordered, based on the Water Act and in several separate decisions, that the regional water authorities (ELY Centre for South Ostrobothnia and ELY Centre for North Ostrobothnia) should assess the negative effects of regulation on lamprey populations, implement measures to compensate them and monitor the success of these measures. Furthermore, some mitigation measures in these rivers have been carried out on a voluntary basis.

When the attempts to rehabilitate lamprey populations in the River Perhonjoki were initiated in the early 1980s (Ojutkangas et al. 1995), there was no prior experience of rehabilitating river lamprey populations and furthermore there were substantial gaps in knowledge of the ecology of river lamprey. In the 2000s, knowledge of the life history of river lamprey has increased (e.g. Fine et al. 2004, Jang and Lucas 2005, Gaudron and Lucas 
2006, Masters et al. 2006, Goodwin et al. 2008, Nika and Virbickas 2010, Taverny et al. 2012, Aronsuu and Virkkala 2014, Silva et al. 2015, Aronsuu et al. 2015, Aronsuu and Tertsunen 2015), and numerous studies have been conducted to study the passage of adult lampreys over anthropogenic barriers (e.g. Lucas et al. 2009, Kemp et al. 2011, Russon et al. 2011, Foulds and Lucas 2013). Yet, the understanding of suitable practices for rehabilitating river lamprey populations in modified rivers is still at a low level and there are gaps in our knowledge about the basic life history of river lamprey and the impact of different anthropogenic pressures on its different life stages. Therefore, even now decisions on mitigation measures are made in the face of considerable uncertainty about their likely effectiveness.

The current situation with other lamprey species is rather similar to river lamprey. The rehabilitation attempts have focused on enhancing passage over migration barriers (Moser et al. 2002, Moser et al. 2011, Jackson and Moser 2012). Nevertheless, there are recent results on the success of translocation of adult Pacific lamprey (Entosphenus tridentatus) within the Columbia River basin (Close et al. 2009, Ward et al. 2012), and in the last few years, sub-yearling larvae have been artificially propagated both in Japan and in the United States of America (R. Lampman, Yakama Nation FRMP, pers. comm.).

As successful conservation and rehabilitation of lamprey populations in regulated rivers all over the world needs all the available knowledge, this paper describes the pioneering work done during the past three decades to study and rehabilitate the river lamprey populations in two Finnish rivers, the Rivers Perhonjoki and Kalajoki. Based on data from habitat surveys and long-term monitoring of larval densities and the number of upstream migrating adults, the negative effects of various anthropogenic activities are assessed. These data, with the estimates of the number of emigrating transformers, are further used to evaluate the success of the rehabilitation measures including translocations of adult lampreys, stocking of sub-yearling larvae, river restoration and mitigation of hydropeaking. Telemetric tracking and tagging experiments were used to determine the efficacy of fishways.

In the studied rivers, several anthropogenic pressures and mitigation measures impacted on lamprey populations simultaneously, which renders it impossible to estimate quantitatively the effects of individual factors. Nevertheless, based on our experience and on the literature we share our view on the most likely reasons and mechanisms for both declines and increases in the abundance of life stages of lamprey populations. 


\section{STUDY AREA}

The River Perhonjoki flows into the Bothnian Bay, the northernmost part of the Baltic Sea at $63^{\circ} 54^{\prime} 42^{\prime \prime} \mathrm{N}, 23^{\circ} 8^{\prime} 13^{\prime \prime} \mathrm{E}$ (Fig. 1). Its drainage area is $2523 \mathrm{~km}^{2}$, and the mean discharge (MQ) $21 \mathrm{~m}^{3} \mathrm{~s}^{-1}$ (mean annual maximum discharge [MHQ] $138 \mathrm{~m}^{3} \mathrm{~s}^{-1}$, mean annual minimum discharge [MNQ] $3.0 \mathrm{~m}^{3} \mathrm{~s}^{-1}$ ). The length of the river is $140 \mathrm{~km}$ and its overall drop $180 \mathrm{~m}$. For this study the river was divided to seven study sections: P1 riverkilometer (rkm) 0-23, P2 rkm 23-33, P3 rkm 33-41.5, P4 rkm 41.5-48.5, P5 rkm 48.5-52, P6 rkm 52-63 and P7 rkm 63-93, (Fig. 1 and Appendix 1). Several large-scale regulation measures have been carried out in the river during the last 100 years, especially in the early 1980s (Appendix 1). In the 1980s, a reservoir and a hydroelectric power plant (total drop $21.5 \mathrm{~m}$, turbine type Kaplan, operating capacity 7.5 MW) were constructed on the lower part of the river, Kaitfors, rkm 33. In addition, discharge of the river is regulated by three older reservoirs in the upper part of the catchment. The main tributary in the lower part of the River Perhonjoki is the River Ullavanjoki (Appendix 1), with drainage area of $413 \mathrm{~km}^{2}$ and total length $41 \mathrm{~km}$. The fast-flowing sections of the River Ullavanjoki have been dredged slightly, but otherwise its hydromorphology has not been affected.

The River Kalajoki is situated north from the River Perhonjoki and enters the Bothnian Bay at $64^{\circ} 17^{\prime} 22^{\prime \prime} \mathrm{N}, 23^{\circ} 54^{\prime} 57^{\prime \prime} \mathrm{E}$ (Fig. 1). The drainage area of the river is 4260 $\mathrm{km}^{2}$ and the mean discharge is $29 \mathrm{~m}^{3} \mathrm{~s}^{-1}$ (MHQ $246 \mathrm{~m}^{3} \mathrm{~s}^{-1}$, MNQ $4.1 \mathrm{~m}^{3} \mathrm{~s}^{-1}$ ). Its length is 110 $\mathrm{km}$ and total drop $100 \mathrm{~m}$. The middle and the uppermost parts of the river ( $\mathrm{rkm} \mathrm{45-110)}$ are heavily modified. In the 1970s and early 1980s, four hydroelectric power plants (HPP) were built on the river and hydropeaking was initiated. the Lowermost of the HPPs was built in Hamari and its total drop was $7 \mathrm{~m}$, turbine type Kaplan and operating capacity 2.5 MW. Furthermore, river flow is regulated by nine small lakes or reservoirs in the upper part of the catchment. In the 1970s, after the building of new reservoirs, the upper and middle parts of the river in particular suffered from oxygen depletion. The lowermost 45 $\mathrm{km}$ of the river is less modified, yet regulated in many ways (Appendix 2). For this study the lowermost part of the river was divided to three sections: K1 rkm 0-12, K2 rkm 12-22.5 and $\mathrm{K} 3 \mathrm{rkm}$ 22.5-45 (Appendix 2). The main tributary of the River Kalajoki, the River Vääräjoki, with drainage area of $951 \mathrm{~km}^{2}$ and total length of $101 \mathrm{~km}$, enters the River Kalajoki at its lower end ( $\mathrm{rkm}$ 9). It is the only significant tributary below the lowermost 
insurmountable dam. Most of the fast-flowing sections of this tributary have been dredged and some of them later restored. The flow of the River Vääräjoki is not regulated.

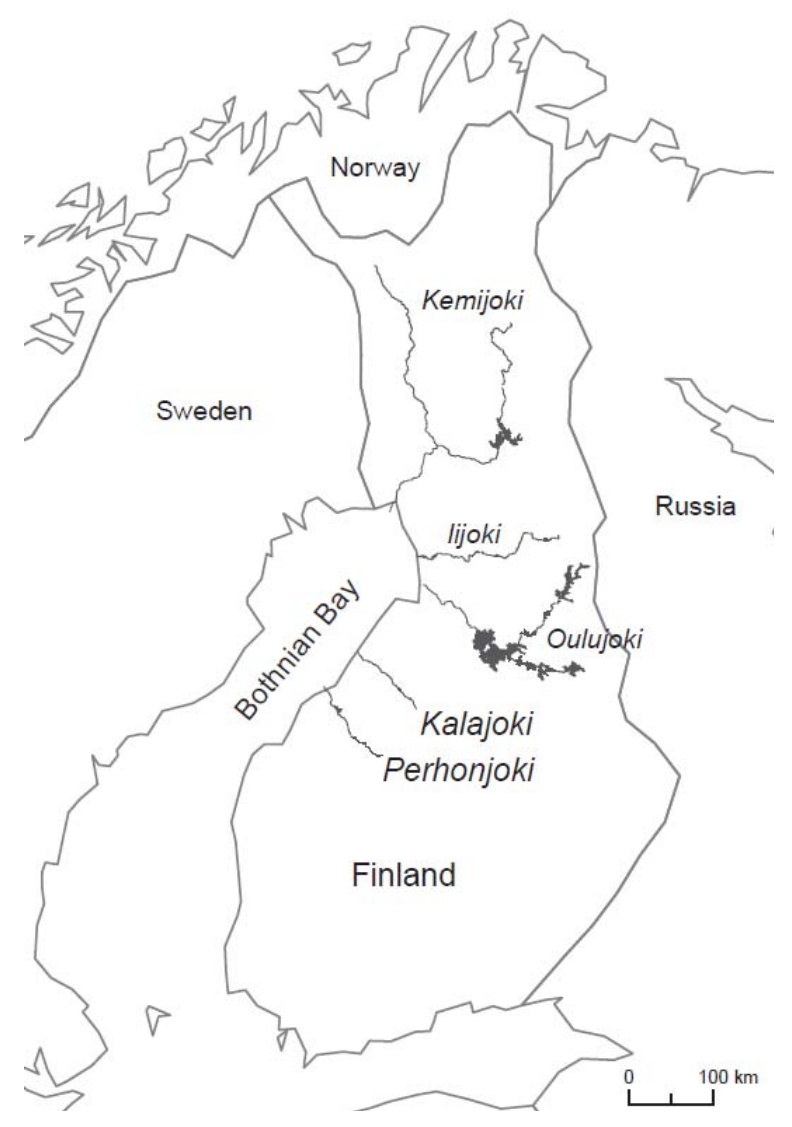

FIGURE 1 Map showing the locations of the Rivers Perhonjoki and Kalajoki and three large rivers (Oulujoki, Iijoki and Kemijoki) flowing into the northern part of the Bothnian Bay.

The water quality is typical of rivers entering the east coast of the Bothnian Bay. The water is humic and, especially during high flows, the content of suspended solids is high. Due to widespread digging of drainage ditches and the release of acid sulphides to rivers, water $\mathrm{pH}$ has occasionally reached a low level and simultaneously the concentration of metals (e.g., $\mathrm{Al}, \mathrm{Fe}, \mathrm{Cd}$ ) has been high. The acidification problem is most severe in the lowermost part of the River Perhonjoki, where $\mathrm{pH}$ values less than 5.5 have been detected almost every year and occasionally values lower than 5 (Fig. 2). In the River Kalajoki, pH values lower than 5.5 have been rare. 


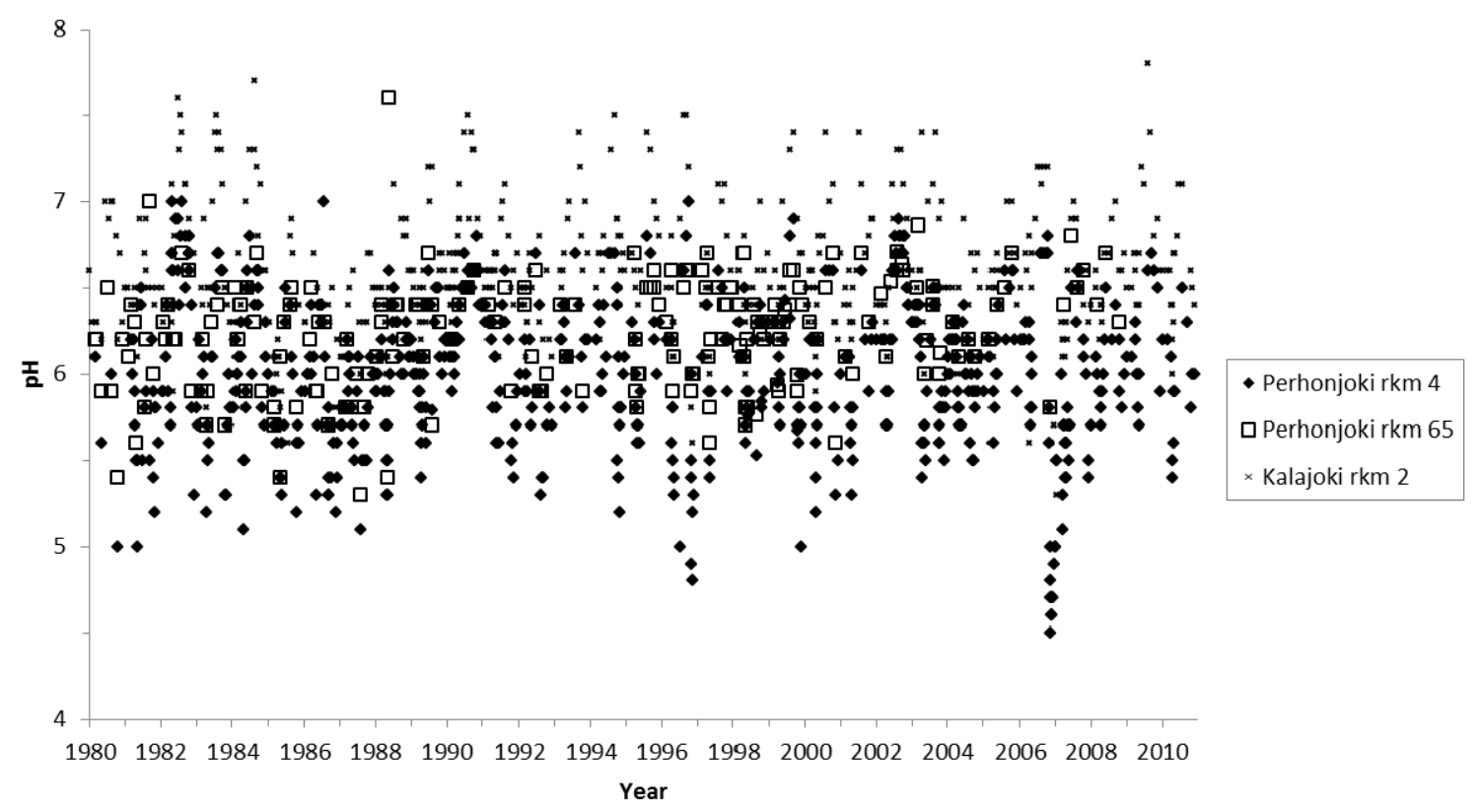

FIGURE 2 Water $\mathrm{pH}$ in the lower end (Perhonjoki rkm 4) and middle part (Perhonjoki rkm 65) of the River Perhonjoki and in the lower end of the River Kalajoki (Kalajoki rkm 2) in 1980-2010. Data from the Environmental Information System Hertta. 


\section{METHODS USED FOR MONITORING CHANGES IN LAMPREY POPULATIONS AND LARVAL HABITATS}

\subsection{The number of upstream-migrating adults, fishing mortality and escapement}

The number of upstream-migrating adult lampreys, their river fishing mortality and escapement (= number of upmigrants - catch, an index of number of individuals starting wintering) were monitored in the Rivers Perhonjoki and Kalajoki from the early 1980s using the daily catch record data provided by local fishermen and mark-recapture.

In the River Perhonjoki, nearly all lamprey fishermen (8-22, average 12) recorded their catches in 1981-2010 and their share of the total catch was estimated to be over $95 \%$.

In the River Kalajoki, almost every lamprey fisherman (24-30) recorded his daily catch and effort during the period 1978-1989, except in 1979 and 1980. The catch of other fishermen was estimated by personal interviews. The recording has been continuous since 1990, and on average 16 (range 12-20) fishermen, with a 70-95\% share of the total annual catch, recorded their daily catch and effort. The yearly catch of other fishermen was estimated by a postal survey, which was carried out every other year. Their catch in the years between postal surveys was estimated by linear interpolation. In the 1990s and 2000s, lamprey fishing was prohibited during one weekend (2 days) during the catching seasons in most years. For those days, the daily number of upstream-migrating lampreys was linearly interpolated from the estimated number of upstream-migrating individuals one day before and one day after the prohibition.

In most years, when the catch was recorded, the fishing mortality and the number of upstream migrating adults were estimated by a mark-recapture method. In the River Perhonjoki, the method was first used in 1981 and the study has been carried out yearly, except 1987-1992, 1995, 2001 and 2007. The number of marked release groups each consisting of about 500 marked lampreys, has usually been 3 or 4 but occasionally 2 or 5 . In 2009 , only one group was released. The yearly average of released marked lampreys was 1780 .

In the River Kalajoki, the study was not carried out in 1987-1989 and 1992. In the 1980s, on the average 1754 tagged lampreys in 3-4 (average 4) separate groups were released annually. In the 1990s, the average number of release groups was 3 and the 
average number of released lampreys was 1495 individuals. In the 2000s, the availability of lampreys for marking was restricted due to low catches, and thus the average number of release groups and released lampreys were only 2 and 789, respectively.

Lampreys for marking were purchased from the local fishermen, who kept them in livewells before marking. Lampreys were marked with group-coded anchor tags, which were attached to the muscle behind the first dorsal fin. In the River Kalajoki, marked lampreys were released to the sea approximately $1.5 \mathrm{~km}$ from the river mouth, and in the River Perhonjoki to the estuary approximately $3 \mathrm{~km}$ downstream from the first traps. All the traps for recapture situated in the lowermost part of the study sections P1 and K1.Based on earlier observations (Laukkanen 1984), it was assumed that $2 \%$ of the total number of marked lampreys did not enter the rivers after release. The fishing mortality induced by the group of fishermen recording carefully their daily catches and the number of marked lampreys in the catch from each release group was estimated by

$$
\mathrm{u}^{\prime}=100 \mathrm{r}^{\prime} /(0.98 \mathrm{~m})
$$

where $\mathrm{u}^{\prime}=$ proportional fishing mortality by the above-mentioned group $(\%), \mathrm{r}^{\prime}=$ their catch of marked lampreys and $\mathrm{m}=$ number of marked lampreys released. The fishing mortality was estimated separately for each release group for a time period during which discharge and fishing effort were constant or for a period of typically 2-3 weeks. The time periods used were decided after the fishing season when all data were available. The size of the subpopulation that migrated into the river during the given time period was estimated by

$$
\mathrm{N}_{\mathrm{sb}}=100 \mathrm{C}^{\prime} / \mathrm{u}^{\prime}=100 \mathrm{C}^{\prime} 0.98 \mathrm{~m} / \mathrm{r}^{\prime} \text {, }
$$

where $\mathrm{N}_{\mathrm{sb}}=$ estimated subpopulation size, $\mathrm{C}^{\prime}=$ total catch by the above-mentioned group of fishermen, and $\mathrm{u}^{\prime}=$ their fishing mortality estimate.

In most years the fishing effort was lower during the beginning and end of the season, typically in August and late October. For those periods, the daily fishing mortality $\mathrm{u}^{\prime \prime}$ was estimated based on the ratio between the daily fishing effort in those periods $\left(\mathrm{f}^{\prime \prime}\right)$ and the daily fishing effort $\left(\mathrm{f}^{\prime}\right)$ for the nearest period for which the fishing mortality had been estimated by the mark-recapture method. Thus,

$$
u^{\prime \prime}=100\left(1-\exp \left(\left(f^{\prime \prime} / f^{\prime}\right) \ln \left(1-u^{\prime} / 100\right)\right)\right)
$$

The size of the subpopulation migrating during that period was estimated as $\mathrm{N}_{\mathrm{sb}}$ above in equation 2-3.1, mutatis mutandis.

The total number of upstream-migrating adult lampreys $(\mathrm{N})$ was then estimated as the sum of all the subpopulations $\left(\mathrm{N}_{\mathrm{sb}}\right)$ and the estimated number of migrants during the fishing prohibition period (see above). The estimate of proportional fishing mortality was obtained by

$$
\mathrm{u}=\mathrm{C} / \mathrm{N},
$$


where $\mathrm{C}=$ the estimate of total catch of all fishermen (= the mark checking record keepers, other record keepers and the fishermen interviewed or replying to the postal survey ) (see above).

The escapement (Esc), the number of the individuals surviving the fishery and carrying on their migration towards the spawning grounds, was estimated simply by

$$
\mathrm{Esc}=\mathrm{N}-\mathrm{C}
$$

No confidence intervals for the estimates of $\mathrm{N}, \mathrm{u}$ or Esc can be easily obtained because of the multifaceted nature of the data used in their estimation. If $m, C^{\prime}$ and $r^{\prime}$ were assumed precise (no random error) and accurate (unbiased) the proportional $95 \%$ confidence intervals for the Petersen estimate of $\mathrm{N}$ would be from \pm 5 to $\pm 10 \%$ for the typical values of $\mathrm{m}, \mathrm{C}^{\prime}$ and $\mathrm{r}^{\prime}$ in this study.

Furthermore, the annual Kalajoki catch estimates contain some random error due to the fact that they are partly based on non-recorded catches recollected by the fishermen after the season. However, the effect on precision is small as the non-recorded catch was typically estimated to be only 5-15\% of annual catch. In the River Perhonjoki almost all catches were recorded.

The effect of the additional random error on the estimate of the migrating population during the short periods of fishing prohibition can also be considered very small due to their low proportion of the total season length. However, a rough extrapolation from the first and last catches per effort at the very beginning and end of the season suggests that some $5-15 \%$ of the adult lampreys may have migrated before and/or after the catching season in different years. This was not compensated for and therefore induces some negative bias (i.e. underestimation of the number of upstream-migrating adults and escapement, and overestimation of fishing mortality).

It was assumed that all recaptured marked lampreys were recorded. This is selfevidently improbable and therefore induces the bias of overestimation of the $\mathrm{N}$ and Esc and underestimation of $\mathrm{u}$. This bias thus contrasts with the previous one and may be a couple of percent higher in the River Perhonjoki than in Kalajoki.

Some assumptions that cannot be evaluated were also made: the temporal distribution of fishing effort of the non-recording fishermen in Kalajoki within the season was assumed equal to that of the record keepers; $2 \%$ of the marked individuals in the sea close to the River Kalajoki were assumed not to enter the river but every individual released in the estuary was assumed to enter the River Perhonjoki; marks were assumed not to drop off and not to affect mortality or migration activity of lampreys.

The estimates of C, N, u and Esc before 1995 were collected from the data banks of the ELY Centres. 


\subsection{Densities of larvae older than one year}

Larval densities were estimated from sediment samples (thickness $10-15 \mathrm{~cm}$, area $\approx 500$ $\mathrm{cm}^{2}$ ) taken by a shovel and sieved using a $1 \mathrm{~mm}$ mesh. Larvae were collected and counted, and the total length of each larva was measured. Later they were released the sampling site.

In the River Kalajoki in 1984-1995, sampling was performed with the protocol of taking 20 samples per sampling site, two samples from every depth zone from $10 \mathrm{~cm}$ to $100 \mathrm{~cm}$ with $10 \mathrm{~cm}$ increments. If for some reason (e.g. stony substratum) all samples could not be taken, the total density of larvae for that site was estimated based on the samples taken. Sampling sites were mostly constant from year to year, but occasionally some new sites were added and in some years only a portion of the sites were sampled. The total number of sampling sites between rkms 1 and 45 varied from 52 to 73 . The sampling was carried out between late June and late August.

Since 1999, a nested sampling protocol has been used. Four slow-flowing river sections (K1: rkm 8-10, K2: rkm 14-16 and rkm 18-20 and K3: rkm 34-37) in the main channel and one slow-flowing section in the lower end of the main tributary, Vääräjoki were selected for monitoring. On each section, 10 sites with substratum suitable for lamprey larvae were selected, marked with a metal rod in the river bank and their positions recorded using a GPS-device. Fourteen samples were taken from each site, two samples per depth from 10 to $70 \mathrm{~cm}$ with $10 \mathrm{~cm}$ increments. The total sampled area in a sampling site was $0.7 \mathrm{~m}^{2}$. The measured water depth was standardised to match with the water depth at a discharge of $10 \mathrm{~m}^{3} \mathrm{~s}^{-1}$. Sampling was performed in 1999, 2001, 2005, 2007 and 2010 in late July or August, when discharge was lower than $15 \mathrm{~m}^{3} \mathrm{~s}^{-1}$.

In the River Perhonjoki in 1982-2004, the same protocol was used as in the River Kalajoki in 1984-1995 with the exception that in 1982 and 1985 a small proportion of samples was taken with an Ekman-Birge grab. The number of sampling sites between rkms 0 and 60.5 was 191 and they were sampled five times (1982, 1985, 1993, 1999, and 2004). In 2007 and 2010, nested sampling similar to the River Kalajoki was used. In the main channel, seven slow-flowing sections were selected for monitoring (P1: rkm 4-5 and rkm 17-20, P2: rkm 22.5-23, P5: rkm 49-51 and rkm 53-54, P6: rkm 59-61, P7: rkm 71-72). In addition, one study section was situated on the tributary Ullavanjoki at rkm 27-28. Sampling in most of these sections was carried out in 2007 and 2010. However, in section P7 and in the River Ullavanjoki nested sampling was already used in 2004.

Both the proportional occurrence (\% of sites with larvae) in sampling sites and the average larval density in study sections were used to reflect the state of the larval subpopulation in different study sections. In some years, exact density data were not available, and therefore only the proportional occurrence was used. The significances of differences in larval densities between years in a particular section and between sections in a particular year were tested using Kruskal-Wallis test with pairwise comparisons (Dunn's test with Bonferroni adjusted p). 


\subsection{Abundance of sub-yearling larvae}

The success of restoration of fast-flowing areas of the River Kalajoki was monitored by studying the changes in abundance of sub-yearling larvae below certain restored riffles. Sampling sites were situated at rkms 10, 16 and 42. At each site, 250 samples were taken. Monitoring was performed in early August 50-300 m below the selected riffle areas in the soft-bottomed sampling sites, where water depth was less than $50 \mathrm{~cm}$. In addition to sampling in the main channel, one site on the River Vääräjoki (rkm 17 [26 km from the sea]) and two sites in the River Siiponjoki (rkms 2 and 6) were selected as control sites. Only 50 samples were taken annually at these sites due to higher larval densities. Samples were taken using a split plastic tube, which was horizontally slid under the sediment surface layer. A sample was approximately $4 \mathrm{~cm}$ thick and its area was approximately 350 $\mathrm{cm}^{2}$. Each sample was sieved using a $600 \mu \mathrm{m}$ mesh. Larvae were then collected and counted, and the total length of each larva was measured. Larvae with a total length less than $25 \mathrm{~mm}$ were considered to be sub-yearling (Nyberg et al. 2002). The monitoring was performed annually in 2000-2010, except 2004 due to high discharge. Sampling at the control sites was initiated in 2001.

\subsection{Downstream migration of transformers}

The number of migrating transformers was monitored using drift nets with an opening diameter of $48 \mathrm{~cm}$ and total length of $180 \mathrm{~cm}$. The cone-shaped part of the net was made of $5 \mathrm{~mm}$ mesh. A collection bag $(\varnothing 20 \mathrm{~cm}$ and length $40 \mathrm{~cm}$ ) with mesh of $3 \mathrm{~mm}$ was attached at the end of the conical section.

The drift nets were attached with ropes to a bridge or a rope crossing the river. Monitoring was performed during spring floods. Consequently the current speed was high in all monitoring sites. Weights and buoys were used to keep the whole drift net mouth just below water surface. As the transformers migrate almost solely during night (e.g. Sjöberg 1980, Bracken and Lucas 2013), the drift nets were set in the river in the evening approximately at sun set and emptied in the next morning after sun rise.

The number of migrating transformers from the river sections above Kaitfors HPP in the River Perhonjoki (P3-P7, Appendix 1) was estimated by catching lampreys in the outlet channel of the HPP in years 2002-2010. Usually ten drift nets were used, but occasionally fewer. The success of stockings of sub-yearling larvae in the River Ullavanjoki was evaluated by estimating the number of emigrating transformers in 2002-2005 in the lower end of the river with 8 drift nets and in a strait in the reservoir $3.2 \mathrm{~km}$ below Ullavanjoki using 6 drift nets per night.

The catching period in the River Ullavanjoki began in the spring as soon as drifting ice-floes no longer prevented trapping, and was halted when discharge went down and no, or only occasional, lampreys were caught. The yearly trapping season lasted for 16-22 days (average 18 days). The average number of yearly trapping days was 14 (range 10-19). In the River Perhonjoki, trapping could be commenced earlier, because there was no ice or 
ice-floes in the outlet channel. The trapping season lasted for 21-32 days (average 27 days) and there was only a single two-day pause in trapping in 2003.

The average proportional fishing mortality of drift net set $(\mathrm{u})$ was estimated by a mark-recapture method. Migrating transformers were caught and marked by fin clipping and then released about $1 \mathrm{~km}$ above the trapping site. In the River Perhonjoki, 1,507 transformers were tagged and released, 12 of which were recaptured. Thus, $u=0.8 \%$ (95 $\%$ confidence interval 0.4-1.3\%, assuming a hypergeometric distribution of $\mathrm{r}$ ). In the two River Ullavanjoki sites, 1,097 and 1,048 marked transformers were released and 45 and 20 recaptured, respectively. Thus, fishing mortality estimates were $4.1 \%$ (3.0-5.4 \%) and 1.9 $\%(1.6-2.9 \%)$.

When estimating the total number of migrating transformers during a night, $\mathrm{u}$ was assumed to be simply proportional to fishing effort (= number of traps), and inversely proportional to discharge. Consequently, the estimate of the total number of migrating transformers in the catching season $(\mathrm{N})$ was estimated by

$$
\mathrm{N}=\sum_{\mathrm{n}=1}^{\mathrm{t}}\left(\mathrm{C}_{\mathrm{n}}\left(\mathrm{f}_{\mathrm{mr}} / \mathrm{f}_{\mathrm{n}}\right)\left(\mathrm{Q}_{\mathrm{n}} / \mathrm{Q}_{\mathrm{mr}}\right)\right) \mathrm{m} / \mathrm{r}
$$

where $C_{n}=$ the number of transformers caught during trapping night $n, f_{m r}=$ the number of traps during mark-recapture night $r, f_{n}=$ the number of traps during trapping night $\mathrm{n}, \mathrm{Q}_{\mathrm{n}}=$ discharge during the trapping night $\mathrm{n}$ and $\mathrm{Q}_{\mathrm{mr}}=$ discharge during the markrecapture night $\mathrm{mr}, \mathrm{t}=$ total number of trapping nights $\mathrm{m}=$ the number of marked and released transformers, $\mathrm{r}=$ the number of marked transformers recaptured.

Note: In the equation 1-3.4, $\mathrm{m} / \mathrm{r}=1 / \mathrm{u}$. The simple scaling of $\mathrm{u}$ by the $\mathrm{f}$ and $\mathrm{Q}$ proportions is a simplified approximation for low values of $u$ and rather small changes in proportions. For large $u$ (tens of percent) and changes in $f$ and $Q$ proportions, $u$ should first be transformed to instantaneous fishing mortality $\mathrm{F}$ and only scaled after that as in formula 3-3.1.

The discharge in the outlet channel of the Kaitfors HPP in the River Perhonjoki was approximately $45 \mathrm{~m}^{3} \mathrm{~s}^{-1}$ for most of the trapping time and most of the water from the reservoir discharged through it. Discharge in the flood channel was typically low, but occasionally, when inflow to the reservoir was high, discharge in the flood channel was much higher than in the outlet channel. When estimating the total number of transformers migrating downriver from the reservoir through the HPP and the flood channel, it was assumed that the number of migrating transformers was directly related to discharge.

During the trapping period, there were some days without trapping. On those days, the daily number of migrating transformers was estimated by linear interpolation from the estimated number of migrating individuals in the days before and after the pause in trapping.

In a boreal river, the drift net method for estimating the number of migrating transformers is vulnerable to some biases. Discharge is typically low and water temperature close to zero during the winter time. The trapping results from the outlet channel of the Kaitfors HPP, and observations by Fogelin (1972) and Sjöberg (1980), suggest that migration of transformers in boreal rivers is associated with increasing flow 
and water temperature in spring and, opposite to more southern rivers (e.g. Bracken and Lucas 2013), transformers do not emigrate in winter. In the River Ullavanjoki, trapping was possible only after all ice-floes had disappeared. An unknown proportion of transformers had migrated before that. This proportion may have varied considerably from year to year because of the inter-annual variation in ice conditions and melting.

The fishing mortality of traps varies with the river discharge, but the form of the relationship has not been studied and it probably varies from site to site. Therefore, assuming direct proportionality may induce bias in the results. Another source of error is the fact that debris clogs traps and accordingly, the amount of debris affects the fishing mortality. Furthermore, confidence intervals for population estimates are wide as recapture rate was low.

Ice-floes did not harm trapping in the outlet channel of the Kaitfors HPP and therefore it was possible to begin already before the migration season. Furthermore, the amount of debris in the channel was low and discharge during the migration season was rather homogenous. Consequently, the results from the River Perhonjoki are more reliable than the results from the River Ullavanjoki. However, the assumption that the number of transformers was directly proportional to discharge through the HPP and flood channel may bias the results to some extent, and the low number of re-captured transformers after tagging led to a broad confidence interval.

\subsection{Success of upstream-migrating adult lampreys at passing fishways}

Lampreys used in the radio-telemetry experiments were captured by the local fishermen in the estuaries or the lowermost riffles of the Rivers Perhonjoki or Kalajoki one to two days before tagging. Lampreys were selected so that the weight of a transmitter (Advanced Telemetry Systems, weight 1.2-1.3 g) did not exceed $2 \%$ of the total weight of a lamprey. Before the implantation of transmitters, lampreys were anaesthetized with benzocaine (50 $\mathrm{mg} \mathrm{l}^{-1}$ ) and their length and weight were measured. Then, a $2 \mathrm{~cm}$ longitudinal incision was cut in the ventral midline of the posterior end of the body cavity and a tag was inserted there. An injection needle was used to pass the antenna through the body wall approximately $3 \mathrm{~cm}$ posterior to the incision. The incision was closed with sutures and cleaned with iodine (Betadine ${ }^{\circledR}$ ). Lampreys were transferred to an aerated tank and allowed to recover. Before release, lampreys were held for a week in aerated tanks or in livewells in the river nearby the release site.

Nineteen lampreys were radio-tagged. Nine of them were released on 20 Sept. 2006 at rkm 32 of the River Perhonjoki to the lower end of the flood channel beside the Kaitfors HPP (Appendix 1). In the experiment conducted in 2007, two groups of five lampreys were released on different occasions (17 Sept. and 1 Oct.) to the River Kalajoki at rkm 21.6, approximately $350 \mathrm{~m}$ below the Vivunkumpu weir (Aronsuu et al. 2015) (Appendix 2).

The movements of tagged lampreys were tracked with a telemetry receiver equipped with a four-element Yagi antenna. In the River Perhonjoki, lampreys were detected twice a week mainly by driving along roads beside the river with a vehicle fitted with a Yagi antenna. The accuracy of positioning was approximately $100 \mathrm{~m}$. In the River Perhonjoki, a telemetry receiver with underwater Yagi antenna placed in the technical fishway, which 
exits to the reservoir, monitored continuously the assigned channels. In the river Kalajoki, the locations of lampreys were monitored almost daily during the first week after release and after that twice or thrice a week. The positions of lampreys were located with approximately 5-10 $\mathrm{m}$ accuracy.

In addition to telemetry, the efficacy of the Kaitfors fishway complex was studied by tagging lampreys with group coded anchor tags and catching with a fyke net all the lampreys that had passed the fishway. On 12 Sept. 2006200 lampreys that originated from the catch in the lowermost part of the river Perhonjoki were tagged. One hundred of them were released at the lower end of the flood channel $2.5 \mathrm{~km}$ downstream from the regulation dam and the other 100 lampreys were released just below the $320 \mathrm{~m}$ long fishway. A fyke net was set in the reservoir about $10 \mathrm{~m}$ above the fishway and the fences of the net were attached to the bank on both sides of the outlet of the fishway so that lampreys that passed the fishway were forced to swim into the trap, if they continued migration upriver. The trap was emptied 12 times during the 6 week trapping period. The tag codes of the recaptured lampreys were recorded and lampreys were released above the trap.

\subsection{The quantity and quality of larval habitats}

The quantity and quality of larval habitats were evaluated in the River Kalajoki in 1995 and 1996. Based on the experience gathered, the methods were developed slightly before the evaluation was conducted in the river Perhonjoki in 1998.

River channel was divided into slow- (pools) and fast-flowing (glides, runs and riffles) sections. In each slow-flowing section, habitat characterization was made along study lines perpendicular to stream flow with $100 \mathrm{~m}$ increments starting $50 \mathrm{~m}$ downriver from the lowermost end of the fast-flowing section. Characterisation was made on both sides of the river. The first sample point of each study line was standardised to the point where the shoreline was situated at a discharge of $10 \mathrm{~m}^{3} \mathrm{~s}^{-1}$. Six further characterisations were made at $1 \mathrm{~m}$ intervals and after that if needed at $2 \mathrm{~m}$ intervals. The last characterisation of the line was made at the point where water depth was $1 \mathrm{~m}$. In the river Perhonjoki, the first sample point was $0.1 \mathrm{~m}$ from the shoreline and points close to shoreline were more frequent than in the River Kalajoki $(0.1,0.4,0.9,1.6,2.5,3.5$...m). Otherwise methods used in the River Perhonjoki were similar to those used in the River Kalajoki.

At each sample point, water depth and the depth of soft sediment were measured using an acrylic tube (diameter $54 \mathrm{~mm}$ ). Furthermore, substrata were typified as follows: 1 ) inorganic particles larger than coarse gravel, 2) gravel, 3) coarse to very coarse sand, 4) clay, 5) very fine to fine sand, 6) fine sand mixed with fine particle organic matter, 7) fine organic matter, 8) coarse organic matter or 9) roots of water plants. The typification was conducted according to the dominant type, but also the codes of two or more types were used. If the substratum had clear layers of two different soft sediment types, the thickness of both types was recorded.

All water depth measurements were standardised to correspond to the depth at 10 $\mathrm{m}^{3} \mathrm{~s}^{-1}$ discharge. The daily discharge and a model showing water levels at each location at 
different discharges were used to standardise water depth measurements as well as to select the starting point for the each study line.

The results were used for rough estimation of lamprey habitats in continuous slowflowing sections. First, substratum types were categorised in three classes: unsuitable (types 1, 2 and 4 as dominant substratum), moderate (type 3, type 3 mixed with types 4 and 9) and good (types 5-8 as dominant substratum and type 3 as dominant substratum mixed with 5-8). Based on these classes and substratum depth, each sample point was categorized as a) unsuitable (unsuitable substrata), b) weak (moderate substrata and good substrata with sediment depth $<5 \mathrm{~cm}$ ), c) moderate (good substrata with substratum depth 5-9 cm) and d) good (good substrata with substratum depth $>9 \mathrm{~cm}$ ) for larval lampreys. For each transect (width $1 \mathrm{~m}$ ) the area of each category was estimated and the average of transects in each continuous slow-flowing section were used to reflect the state of larval habitats in each slow-flowing section. A rough habitat suitability index for the slow-flowing sections was calculated by weighting the estimated mean area $\left(\mathrm{m}^{2} \mathrm{~m}^{-1}\right)$ of categories $\mathrm{a}, \mathrm{b}, \mathrm{c}$ and $\mathrm{d}$ with $0,0.5,1.0$ and 2.0, respectively and summing them.

In the fast-flowing sections, all possible sites where substratum was not rough inorganic matter or hard clay, were observed visually and habitats were characterized along transects. However, the proportion of all larval habitats that were in fast-flowing sections was negligible and results are not shown. 


\section{IMPACT OF ANTHROPOGENIC PRESSURES AND REHABILITATION MEASURES ON RIVER LAMPREY POPULATIONS}

\subsection{The River Perhonjoki}

\subsubsection{Sections below the Kaitfors HPP (P1 and P2)}

The lowermost section of the River Perhonjoki (P1, rkm 0-22) was mostly channelized in 1968-1979 and three block-stone weirs were built in the upper end of the section (Appendix 1). Channelization created a monotonous morphological and hydrological environment resulting in loss of flow refuge and backwaters and elevated flow velocity, and thus depositional bottoms suitable for larval habitat became scarce (Ojutkangas et al. 1995; see also Negishi et al. 2002, Garcia et al. 2012, Elosegi and Sabater 2013). The habitat survey conducted in 1998 verified that both quantity and quality of larval habitats in the P1 were at a very low level (Fig. 3). Furthermore, the habitat survey carried out during restoration planning in 1993 demonstrated that the fast-flowing sections of the P1 were channelized (Aronen 1995) and the amount of potential wintering (Aronsuu et al. 2014) and spawning habitats (Jang and Lucas 2005, Nika and Virbickas 2010, Aronsuu and Tertsunen 2015) were low. The poor quality of physical habitats is likely to explain the low larval density in 1982 before hydrological changes took place (Appendix 1). In addition, low $\mathrm{pH}$ (Fig. 2) and high metal concentration due to leaching from ditched sulphide acid soils may have increased mortality of eggs and larvae (Myllynen et al. 1997) and deteriorated the quality of eggs during the wintering period of adults (Mäenpää et al. 2001). 


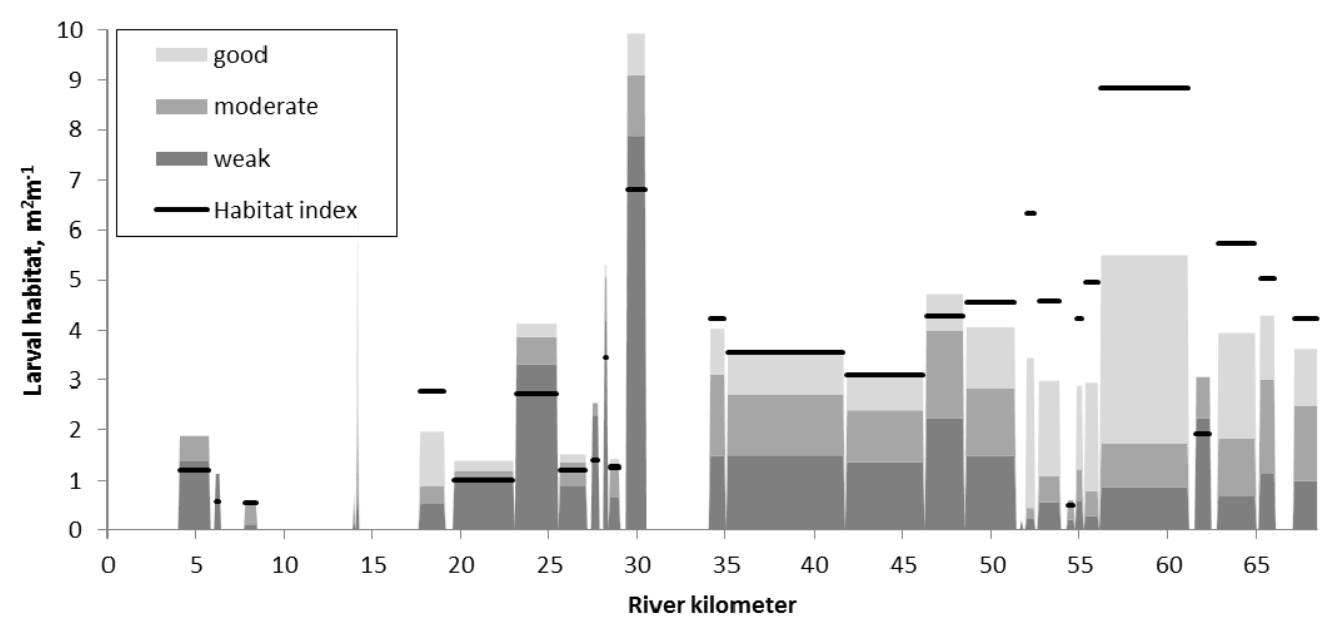

FIGURE 3 The average river lamprey larval habitat availability $\left(\mathrm{m}^{2} \mathrm{~m}^{-1}\right)$ in each continuous slow-flowing section in the River Perhonjoki. Habitat suitability has been divided into four categories based on substratum type and depth: a) unsuitable (not shown), b) weak, c) moderate and d) good. A rough habitat suitability index for slow-flowing sections has been calculated by weighting the estimated mean area $\left(\mathrm{m}^{2} \mathrm{~m}^{-1}\right)$ of categories $\mathrm{a}, \mathrm{b}, \mathrm{c}$ and $\mathrm{d}$ with $0,0.5,1.0$ and 2.0, respectively, and summing them.

In the early 1980s, the morphological state of the P2 (rkm 22-33) was much better than that of the P1. Even though the riffles had been dredged slightly, they offered suitable wintering and spawning sites, and the slow-flowing areas offered a lot of soft sediment bottoms suitable as larval habitat (Ojutkangas et al. 1995). Consequently in 1982 the average larval density in the P2 (8.6 larvae $\mathrm{m}^{-2}$ ) (Appendix 1) was comparable with those of only slightly regulated neighbouring rivers Lestijoki, Isojoki and Tiukanjoki, where the average larval densities in slow-flowing areas (nested sampling protocol) in 2002 were 7.1, 10.2 and 16.3 larvae $\mathrm{m}^{-2}$, respectively (Mäenpää 2002).

Multiple human-induced changes took place in the lowermost part of the river Perhonjoki in the early 1980s (Appendix 1). A hydroelectric power plant and a regulation dam were constructed at rkm 33, Kaitfors. Furthermore, practically all the riffle areas between rkms 22-31 were removed and four block-stone weirs were constructed to replace them. The longest riffle section (rkm 31-33) in section P2 was not removed, but its hydrology was changed dramatically as it was turned to a flood channel with a base flow of $0.3-1.0 \mathrm{~m}^{3} \mathrm{~s}^{-1}$. Furthermore, four concrete weirs were constructed in the flood channel. Hydropeaking at the Kaitfors HPP was initiated in 1983. Due to river engineering measures and hydropeaking, larval densities in section P2 collapsed as described in detail by Ojutkangas et al. (1995) (Appendix 1, Table 1).

During the first years, hydropeaking was intense and caused severe problems by thickening the ice cover and inducing erosion (for details see Ruhanen 1987, Ojutkangas et al. 1995). In 1986, the water flow regulation was mitigated to reduce thickening of the ice and erosion. However, the studies performed in the early 2000s demonstrated that hydropeaking still eroded the river banks in sections P1 and P2 (Sarkki 2005). Due to fluctuating flow, ice cover became thicker especially next to river banks and moved up and down, so increasing erosion. Continuous changes in flow and water level also induced 
erosion, but their effect was estimated to be lower than that of the erosion induced by altered ice conditions (Sarkki 2005).

The larval habitat survey carried out in 1998 revealed that the area of river bed suitable for larvae in section P2 was at a low level, despite one short slow-flowing section (rkm 29.7-30.3), where sand and fine sand had been deposited (Fig. 3). In the P2, the dominant substratum types in slow-flowing sections were coarse inorganic material and clay. If only clay is available, larvae may burrow into it (Smith et al. 2012), but many studies have demonstrated that clay bottoms are rejected by larval lampreys (Lee 1989, Smith et al. 2011, Aronsuu and Virkkala 2014) and exposure to predation is increased in clay bottoms (Smith et al. 2012). It has also been found that inorganic coarse substratum is rejected by lamprey larvae (Lee 1989, Smith et al. 2011), especially by the smaller larvae (Almeida and Quintella 2002, Sugiyama and Goto 2002), which have difficulties in burrowing into it (Quintella et al. 2007).

TABLE 1 The results of Kruskall-Wallis tests and pairwise comparisons (Dunn's test) for differences in larval densities between years in a certain section and between sections in a certain year in the River Perhonjoki in 1982-2004. $\mathrm{p}=$ probability of type I error in Kruskall-Wallis test, $\mathrm{n}=$ the number of sampling sites in section. Different letters indicate significantly different (Bonferroni adjusted $\mathrm{p}<$ $0.05)$ groups in pairwise comparisons. Comparisons of sections are shown vertically ( $)$ and comparisons of years horizontally $(\bullet)$. In every comparison, letter a indicates the group with lowest density.

\begin{tabular}{|c|c|c|c|c|c|c|c|c|c|c|c|c|}
\hline \multirow{2}{*}{$\begin{array}{l}\text { River } \\
\text { section }\end{array}$} & \multicolumn{2}{|c|}{1982} & \multicolumn{2}{|c|}{1985} & \multicolumn{2}{|c|}{1993} & \multicolumn{2}{|c|}{1999} & \multicolumn{2}{|c|}{2004} & \multirow{2}{*}{$\begin{array}{c}\mathrm{p}- \\
\text { value }\end{array}$} & \multirow[t]{2}{*}{$n$} \\
\hline & sect. & years & sect. & years & sect. & years & sect. & years & sect. & years & & \\
\hline P1 & a & $a$ & $9 a$ & $a$ & bc & $a$ & $a$ & $a$ & $a b$ & $a$ & 0.753 & 59 \\
\hline P2 & c & $\mathrm{b}$ & $b$ & $\mathrm{~b}$ & $a b$ & $a$ & $a$ & $a$ & $a$ & a & $<0.001$ & 32 \\
\hline P3 & $a b$ & $a$ & - & - & - & - & a & $a$ & a & $a$ & 0.044 & 18 \\
\hline P4 & c & $b$ & b & $\mathrm{b}$ & a & $\mathrm{a}$ & $\mathrm{a}$ & $\mathrm{a}$ & a & $a$ & $<0.001$ & 35 \\
\hline P5 & bc & $a$ & b & $a$ & c & $\mathrm{a}$ & b & $a$ & b & $a$ & 0.339 & 22 \\
\hline P6 & $a$ & $\mathrm{a}$ & $\mathrm{ab}$ & $a$ & $a b c$ & $a$ & $a$ & a & $a b$ & $\mathrm{a}$ & 0.045 & 25 \\
\hline$p$-value & $<0.001$ & - & $<0.001$ & - & $<0.001$ & - & $<0.001$ & - & 0.001 & - & - & - \\
\hline
\end{tabular}

Hydropeaking increases ice thickness especially close to river bank (Sarkki 2005), so freezing and ice compression may also have reduced suitability of shallow areas for lamprey larvae even if there were still some soft sediments. This suggestion is supported by many studies in northern regulated lakes demonstrating that, in soft bottomed shallow shores, the richness and biomass of benthic fauna have decreased markedly due to freezing and/or ice compression (Palomäki and Koskenniemi 1993, Aroviita and Hämäläinen 2008).

The negative effects of hydropeaking on larval river lamprey are evident, but the effects on other life stages are not well known. The wintering stage of adult river lamprey lasts for 6-8 months in boreal rivers (Aronsuu et al. 2015). Fluctuating water flow and multiple changes in ice processes due to hydropeaking are known to be harmful for wintering fish (e.g. Huusko et al. 2007, 2013, Weber et al. 2013). For example, formation of anchor ice may cause habitat exclusion and energy-intensive migrations. Given that river lampreys do not eat after entering fresh water and they are in an energy-saving hypometabolic state during the winter months (Gamber and Savina 2000), the disturbances are potentially even more detrimental to them than to most fishes and may increase their energetic costs, stress and exposure to predation and consequently increase their mortality and reduce reproductive success. 
Spawning behaviour and survival of the early stages of river lamprey (egg and subyearling larvae) may also be impaired by hydropeaking. For example, the spawning substratum selection and nesting behaviour of river lamprey are affected by flow conditions (Aronsuu and Tertsunen 2014). Furthermore, fluctuation of water level may increase mortality of eggs and sub-yearling larvae as gravel beds are exposed to scouring risk at peak flow and dewatering at off-peak flow (McMichael et al. 2005), and elevated discharge increases downstream dispersion of river lamprey eggs from spawning areas (Silva et al. 2015).

In addition to hydropeaking, changes in the river morphology, due to the channelization in the P1 and substituting riffles with weirs in the P2, is likely to have decreased the wintering and spawning success of adult river lamprey and intensified the negative effects of hydropeaking (e.g. Yrjänä et al. 2002, Persson et al. 2014). Although the block-stone weirs in the P2 offered a lot of crevices for wintering adults to hide in, the current velocity in the weirs was mostly much higher than that selected by wintering river lampreys (Aronsuu et al. 2015). Furthermore, ice formation is delayed in steep weirs and channelized riffles, and thus prominent anchor ice formation induced by hydropeaking (Ruhanen 1987, Sarkki 2005) has most likely hampered wintering adults both in the P1 and P2. As weirs were constructed of block stones, the only gravel bottoms suitable for spawning in section P2 remained in the flood channel (rkm 31-33), where restricted flow $\left(0.3-1.0 \mathrm{~m}^{3} \mathrm{~s}^{-1}\right)$ and occasional high floods may have hampered wintering and spawning of adults, embryonic development and lampreys in their prolarval stage.

To enhance habitats for fish, crayfish and lamprey, the channelized, fast-flowing river sections in the P1 were restored in 2000-2002 with conventional methods developed for salmonids (e.g. Yrjänä 1998). Various in-stream structures, including boulder/cobble ridges, deflectors and groups of boulders, were constructed to increase hydraulic and physical habitat heterogeneity of the dredged riffles and glides. Furthermore, gravel with particle size 8-40 $\mathrm{mm}$ was added into the river to create spawning grounds for salmonids and lamprey. While restoring fast-flowing sections, boulder/cobble dams were constructed at the upper end of riffles and consequently water level in the slow-flowing sections increased typically by 10-20 cm, which decreased their current speed. Moreover, most of the previously blocked side branches of the river were opened.

In section P2, all four block-stone weirs were modified to artificial riffles using diverse in-stream structures, which increased morphological and hydraulic heterogeneity and slightly decreased the gradient of fast-flowing sections. Furthermore, gravel with grain size of $8-40 \mathrm{~mm}$ was added to all artificial riffles. The restorations were carried out in 2002-2003.

In addition to restoring fast-flowing river sections and reopening side branches, two channelized river sections (rkms 12.6-13.3 and 16.1-16.5) with moderate current speed were experimentally restored in 2000 to increase depositional bottoms suitable for larval habitats. In these sections, the channel was slightly broadened and the heterogeneity of straightened river banks was increased by excavating small bays of different sizes on one or both sides of the river. The width of the bays was 2-5 m and their length $10-40 \mathrm{~m}$. Furthermore, a boulder deflector was typically constructed in the upper ends of the bays to further reduce current speed and increase the possibility of fine inorganic material and organic material accumulating into the bays. 
The most recent changes in water flow regulations of the Kaitfors HPP came into force in 2008. According to the court order, hydropeaking in summer was prohibited before July 15. This was assumed to enhance the spawning success of river lamprey and decrease the number of eggs and prolarvae stranding or being washed out from gravel habitat to the inferior habitats downstream, where hatching success (see Silva et al. 2015) and survival of the prolarvae still unable to construct a burrow (see Aronsuu and Virkkala 2014) were assumed to be reduced. Furthermore, the flow regime of hydropeaking throughout the whole year was restricted slightly: When the daily mean discharge (MQ) is less than $14 \mathrm{~m}^{3} \mathrm{~s}^{-1}$, hydropeaking is allowed in four equidistant periods, but the highest allowed discharge is $17 \mathrm{~m}^{3} \mathrm{~s}^{-1}$. When the daily MQ is $\geq 14 \mathrm{~m}^{3} \mathrm{~s}^{-1}$, the HPP must be used continuously and discharge during day time is allowed to be at most $35 \%$ higher than during night time. The regulations for minimum flow remained unchanged: $3 \mathrm{~m}^{3} \mathrm{~s}^{-1}$ from April to October and $2 \mathrm{~m}^{3} \mathrm{~s}^{-1}$ at other times, measured at rkm 18 .

In spite of various mitigation measures, the average larval density in sections P1 and P2 remained low in the 2000s, being less than 1 larva $\mathrm{m}^{-2}$ in both sections in 2010 (Appendix 1). It is likely that poor quality and low availability of larval habitats due to channelization (P1) and hydropeaking (P1 and P2) were still important factors restricting larval production. Habitat surveys conducted in 2013 in the other restored slow-flowing river section (rkm 16.1-16.5) revealed that attempts to increase larval habitats by widening the channel and constructing bays were unsuccessful. The substratum in the bays was coarse inorganic material poorly suited for larval lampreys. Soft material had not accumulated in the constructed bays. According to field observations and aerial photographs, it seemed that ice-floes had eroded boulder deflectors and during high flows the constructed bays were totally submerged, and thus high flows were likely to flush out the material accumulated in bays during low-flow period. However, not all the possible positive impacts of river restoration have been surveyed. For example, it is not known, whether depositional areas formed in many side branches which were reopened in 20002002.

Restoration of the channelized riffles (P1) and weirs (P2) were likely to improve wintering habitats of adult lampreys. However, wintering of adult lampreys may still have been hampered by fluctuating flow and disturbed ice conditions. Furthermore, current velocity in the restored weirs may have been too high for wintering adults (see Aronsuu et al. 2015). Prohibition of hydropeaking in early summer and restoration of weirs and riffles have probably enhanced spawning success and survival of eggs and prolarvae to some extent. However, it is possible that there were still problems in spawning. Gravel added into the weirs and riffles was intended for salmonids and may have been suboptimal for lamprey, as the finest fractions of gravel and sand had been removed by sieving before adding the gravel in the river (see Smith and Marsden 2009, Aronsuu and Virkkala 2014, Aronsuu and Tertsunen 2015).

Furthermore, it is probable that, especially in section P1, frequent peaks of acidity (Fig. 2) combined with high metal concentrations still increases the mortality of lampreys in different stages, although recently some measures have been introduced to reduce leaching from acid sulphate soils (Head of nature conservation, City of Kokkola J. Hannila, pers. comm.). 


\subsubsection{The number of upstream-migrating adults}

In 1981-1984, the average number of lampreys entering the River Perhonjoki during the fishing season was estimated to be 200000 individuals. In that period, the average fishing mortality was $48 \%$ and the average escapement (index of number of lampreys surviving to the beginning of the wintering period) was estimated to be 106000 . In the 2000s, the average of the number of upstream migrating adult lampreys was estimated to be 83000 and the average of escapement 56000 individuals. During the study period, there has been a significant decreasing trend in the number of upstream-migrating adult lampreys entering the River Perhonjoki (linear trend, $p=0.002$ ) (Appendix 1). However, the negative trend in the time series of escapement was not significant $(p=0.11)$.

The collapsed larval density may partly explain the diminished number of upstream-migrating adults as the number of transformers emigrating from the River Perhonjoki has most likely decreased markedly since the early 1980s. However, as the homing behaviour of river lamprey has been suggested to be weak (Tuunainen et al. 1980), it is probable that some lampreys produced by neighbouring rivers enter the River Perhonjoki after their sea phase and therefore the proportional decline in the number of upstream migrating adults was less extensive than the decline in the larval densities. On the other hand, larval river lampreys release common migratory pheromones (Fine et al. 2004) to which adult river lampreys are sensitive (Gaudron and Lucas 2006). Therefore, it is probable that pheromones spread by river water are also a cue for adult river lampreys seeking a spawning river and likely have some effect on their behaviour when they are selecting the river into which they migrate (see Vrieze et al. 2010, 2011, Aronsuu et al. 2015). Consequently, it is likely that the low number of upstream-migrating adult lampreys since the mid 1980s is to some extent associated with the depressed pheromonal migration cue for upstream migrating lampreys. However, river lamprey catches in the other rivers discharging into the Bothnian Bay have also decreased markedly during the last three decades (Tuunainen et al. 1980, Mäkelä and Kokko 1990, Sjöberg 2011) indicating a wider scale reduction of the river lamprey populations in the Bothnian Bay. This is likely to be partly associated with the massive river regulation measures in the rivers flowing in the Bothnian Bay (see also lesson 1 in chapter 5).

Even though the number of adults starting wintering below the Kaitfors HPP is rather well known, winter mortality and consequently the numbers of spawners is unknown. However, even if the number of spawners was known, one still would not have a reliable understanding of the minimum level of spawners required for normal larval production. It is possible that over decades the escapement has decreased to such a low level that the fecundity of spawners would be a factor limiting recruitment, if the river was close to its natural state. However, it is probable that in the current situation various anthropogenic disturbances other than fishing are limiting lamprey population so extensively that restricting fishing and diminishing fishing mortality would not markedly increase larval production and the number of emigrants from the P1 and P2. Furthermore, it should be noted that in the 2000 s approximately $50 \%$ of the lampreys caught in the lower end of the P1 have been used for translocations (12 500 ind. year-1) or for artificial propagation $\left(\approx 2500\right.$ ind. year $\left.^{-1}\right)$ to rehabilitate population upriver from the Kaitfors HPP 
(Tables 2 and 3). Consequently, the actual fishing mortality is currently less than $20 \%$ and the actual escapement higher than its estimate based on $\mathrm{N}-\mathrm{C}$.

\subsubsection{Sections between the Kaitfors and Pirttikoski HPPs (P3-P6)}

Before construction of the Kaitfors HPP, the section P3 (rkm 33-41.5) was mostly riverine and there was estimated to be appreciable area suitable for lamprey larvae (Ojutkangas et al. 1995). However, for unknown reasons the larval density in 1982 was as low as 0.8 larvae $\mathrm{m}^{-2}$. Due to impoundment in 1983, the water level rose by approximately $2 \mathrm{~m}$ and most of the P3 turned to a lacustrine reservoir, although some parts remained riverine (Appendix 1). Nevertheless, water level rose also in the river-like parts and the channel widened.

Before impoundment, the best larval production sites were situated in section P4 (rkm 41.5-48.5) and the average larval density in 1982 was 9.9 larvae $\mathrm{m}^{-2}$ (Appendix 1), and even as high as 16.6 larvae $\mathrm{m}^{-2}$ in the subsection between $\mathrm{rkm} 41.5$ and 45.4 . While constructing the reservoir, the channel from rkm 42 to 46 was embanked and three small riffles were removed (Appendix 1). After impoundment, water level regulation of the reservoir influenced up to the upper end of the section P4 (rkm 48.5), where the only remaining riffle area of the section was situated. In section P5 ( $\mathrm{rkm} \mathrm{48.5-53),} \mathrm{the} \mathrm{average}$ larval density before impoundment in 1982 was 6.0 larvae $\mathrm{m}^{2}$, but no larvae were detected in section P6 (rkm 53-63) (Appendix 1). The hydromorphology of the sections P5 and P6 was not affected by the regulation measures carried out in the 1980s. However, damming prevented adult lampreys from migrating there.

To compensate for the negative effects of regulation measures on lamprey populations, including construction of the insurmountable dam, translocations of adult lampreys above the Kaitfors dam were initiated in 1981 (Table 2, Appendix 1). Lampreys for translocation were purchased mostly from the fishermen catching lampreys in the lower end of the River Perhonjoki, but occasionally, lampreys were translocated from the neighbouring rivers. Lampreys were transferred to the release sites above the Kaitfors HPP during the autumn, mostly in September and October. In 1981-1996, the court ordered that 25000 lampreys should be translocated annually. Occasionally, the annual number of lampreys was less than that, which was compensated by translocating more lampreys in the following years (Table 2). During 1981-1996, in total 385000 adult lampreys were translocated to the sections P4-P6 (Table 2), the majority of which (73\%) were released at the upper end of the P6, just below the Pirttikoski HPP (Appendix 1).

Despite translocations, the larval density in section P6 stayed low and the average larval densities in sections P4 and P5 decreased after massive regulation measures (Appendix 1), in section P4 significantly (Table 1). In 1993, the average larval density in sections P5 and P6 was approximately 1 larva $\mathrm{m}^{-2}$ and no larvae were found in section P4.

Ojutkangas et al. (1995) speculated that sewage water from a dairy could be the reason for low larval densities in the P6. There is still no evidence supporting this suggestion, but according to field observations there are plenty of Fe deposits (Mäenpää and Ojutkangas, pers. obs.) and Myllynen et al. (1997) have shown high iron concentration to be harmful for larval river lampreys. However, habitat surveys demonstrated that there are more larval habitats of better morphological quality in section P6 than in the other sections (Fig. 3). The data from telemetry experiments conducted in 2002 implied that otter 
(Lutra lutra) and mink (Mustela vison) may induce considerable predation mortality on adult lampreys wintering below the Pirttikoski dam in the upper end of the section P6 (Aronsuu et al. 2015, Appendix 1). As transplantations until the mid 1990s focused on the upper end of the section P6, and undoubtedly some proportion of adults transplanted to the lower sections ( $\mathrm{P} 4$ and P5) migrated up to the Pirttikoski dam, it is possible that predation during wintering below the dam markedly reduced the spawning population. Furthermore, flow regulation by the HPP and restricted wintering habitats below the dam may have increased mortality and/or reduced reproduction success. Just below the Pirttikoski dam there was a gravel bar used for spawning by hundreds of lampreys (K. Aronsuu, pers. obs.), It was the only gravel bar known to be suitable for lamprey spawning in section P6. This gravel bar was removed in 1995 to enhance hydropower production.

TABLE 2 The number of adult river lampreys translocated annually to the different sections (P4P7) of the River Perhonjoki in 1981-1996 (A) and 1997-2010 (B).

\begin{tabular}{|c|c|c|c|c|c|c|c|c|c|c|c|c|c|c|c|}
\hline \multirow{2}{*}{$\begin{array}{l}\text { River } \\
\text { section }\end{array}$} & \multicolumn{15}{|c|}{ Number of translocated adults } \\
\hline & 1981 & 1982 & 1983 & 1984 & 1985 & 1986 & 1987 & 1988 & 1989 & 1990 & 1991 & 1992 & 1993 & 1994 & 1995 \\
\hline P4 & 0 & 0 & 5000 & 0 & 0 & 0 & 0 & 0 & 1900 & 9600 & 8333 & 3534 & 0 & 11660 & 0 \\
\hline P5 & 0 & 0 & 0 & 0 & 0 & 0 & 0 & 0 & 0 & 0 & 8333 & 0 & 0 & 0 & 30014 \\
\hline P6 & 10000 & 15000 & 10000 & 27000 & 1000 & 27000 & 29000 & 10700 & 71500 & 18400 & 8333 & 0 & 42857 & 11660 & 0 \\
\hline P7 & 0 & 0 & 0 & 0 & 0 & 0 & 0 & 0 & 14700 & 0 & 0 & 0 & 0 & 0 & 0 \\
\hline Total & 10000 & 15000 & 15000 & 27000 & 1000 & 27000 & 29000 & 10700 & 88100 & 28000 & 24999 & 3534 & 42857 & 23320 & 30014 \\
\hline \multicolumn{16}{|l|}{ B } \\
\hline \multirow{2}{*}{$\begin{array}{l}\text { River } \\
\text { section }\end{array}$} & \multicolumn{15}{|c|}{ Number of translocated adults } \\
\hline & 1997 & 1998 & 1999 & 2000 & 2001 & 2002 & 2003 & 2004 & 2005 & 2006 & 2007 & 2008 & 2009 & 2010 & Total \\
\hline P4 & 13185 & 3922 & 4491 & 9918 & 5995 & 1120 & 11242 & 16450 & 1000 & 17859 & 19766 & 8949 & 5874 & 11532 & 131303 \\
\hline P5 & 0 & 3045 & 6260 & 2597 & 824 & 0 & 2289 & 0 & 0 & 0 & 0 & 0 & 0 & 0 & 15015 \\
\hline P6 & 0 & 5575 & 2011 & 0 & 0 & 1080 & 0 & 0 & 0 & 0 & 0 & 0 & 0 & 1653 & 10319 \\
\hline P7 & 0 & 0 & 0 & 0 & 3441 & 0 & 0 & 0 & 4366 & 0 & 0 & 0 & 0 & 0 & 7807 \\
\hline Total & 13185 & 12542 & 12762 & 12515 & 10260 & 2200 & 13531 & 16450 & 5366 & 17859 & 19766 & 8949 & 5874 & 13185 & 164444 \\
\hline
\end{tabular}

The offspring of adult lampreys translocated into the section P6 were expected to disperse over the years downstream to the sections P4 and P5 and fill their larval habitats. However, as the larval density in section 6 stayed at a low level, the dispersion rate must have been low.

In 1997, by an updated court order, the annual average number of translocated lampreys decreased to 12500 individuals. Simultaneously, the annual stocking of 10 million larvae became a new mandatory measure to supplement the river lamprey population. Since then, sub-yearling lampreys have been artificially propagated and stocked using the methods described in the manual for artificial propagation of lampreys (Vikström 2002). However, detailed methods have been developed all the time based on experience gathered over the years. Prolarvae were reared for 1-2 weeks after hatching and stocked into rivers after reaching a total length of 6-9 $\mathrm{mm}$. Rearing for longer than that was found to be inefficient because the risk of high mortality increased after individuals reached a mean size of $7 \mathrm{~mm}$. Larvae were transferred to the stocking sites in oxygenated plastic bags, and larvae with length $<7.5 \mathrm{~mm}$ should have been stocked in fast-flowing gravel areas while larger ones could be stocked also in soft-bottomed river 
sections under the riffle (see Aronsuu and Virkkala 2014). However, this procedure was not followed precisely and occasionally all larvae were stocked in soft-bottomed sections. Since 2004, all larvae have been stocked in the fast-flowing river sections. In 2009, the court ordered the annual number of stocked sub-yearling larvae to be increased to 15 million individuals.

In 1997-2010, altogether 156600 adult lampreys were translocated and 50 million sub-yearling larvae stocked into the sections P4-P6. After deterioration of spawning sites and suspicion of high predation pressure below the Pirttikoski dam, the transplantations to the section P6 have been reduced. Most of the adult lampreys (84 \%) in 1997-2010 were released at rkm 46, at the section P4 (Table 2). Sub-yearling larvae were mostly stocked into the riffles in the upper ends of the P4 (25 million) and P5 (23 million) (Table 3).

One fast-flowing river section in the upper end of the P4 $(250 \mathrm{~m})$ and two fastflowing sections (in total $400 \mathrm{~m}$ ) in the upper end of the P5, which had earlier been dredged to enhance timber floating, were restored in 1997 using conventional restoration methods.

Despite the changed rehabilitation strategy that focused the measures on the sections P4 and P5 and substituted part of the transplantation of adults by stocking of subyearling larvae and restoration of some riffle areas, larval density has constantly remained low in all four sections (P3-P6) (Appendix 1).

TABLE 3 The number of sub-yearling larvae of river lamprey stocked annually into the different sections (P1-P7) of the River Perhonjoki and into its tributary, the River Ullavanjoki, in 1997-2010.

\begin{tabular}{|c|c|c|c|c|c|c|c|c|c|c|c|c|c|c|c|}
\hline \multirow{2}{*}{$\begin{array}{c}\text { River } \\
\text { section }\end{array}$} & \multicolumn{15}{|c|}{ Number of stocked sub-yearling larvae, millions } \\
\hline & 1997 & 1998 & 1999 & 2000 & 2001 & 2002 & 2003 & 2004 & 2005 & 2006 & 2007 & 2008 & 2009 & 2010 & Total \\
\hline P1 & 1.6 & 0.8 & 3.1 & 1.1 & 1.7 & 1.2 & 0.4 & 0 & 0 & 0 & 0 & 0 & 0 & 0 & 9.9 \\
\hline P2 & 0 & 0 & 0 & 1.5 & 0.5 & 0 & 0 & 0 & 0 & 0 & 0 & 0 & 0 & 0 & 1.9 \\
\hline P3 & 0 & 8.8 & 11.5 & 0 & 0 & 0 & 0 & 0 & 0 & 0 & 0 & 0 & 0 & 0 & 20.3 \\
\hline P4 & 0 & 0 & 0 & 1.3 & 2.2 & 2.9 & 1.4 & 1.9 & 3.8 & 1.6 & 1.8 & 2.9 & 3.4 & 0 & 23.2 \\
\hline P5 & 0 & 0.2 & 1.6 & 0.6 & 3.3 & 5.9 & 0 & 1.6 & 3.6 & 1.2 & 1.8 & 1.3 & 0 & 0 & 20.9 \\
\hline P6 & 0 & 0 & 0 & 0 & 0 & 0 & 0 & 0 & 0 & 0 & 0 & 0 & 0 & 0 & 0 \\
\hline P7 & 0 & 0 & 0 & 1.0 & 4.1 & 11.1 & 4.2 & 7.7 & 9.2 & 11.2 & 13.2 & 13.1 & 20.3 & 2.5 & 97.7 \\
\hline Ullavanj. & 1.7 & 3.8 & 6.8 & 4.1 & 8.2 & 8.3 & 3.7 & 5.1 & 4.4 & 5.8 & 6.6 & 4.6 & 7.7 & 2.5 & 73.2 \\
\hline Total & 3.3 & 13.6 & 23.0 & 9.7 & 20.0 & 29.3 & 9.7 & 16.2 & 21.0 & 19.8 & 23.4 & 21.9 & 31.4 & 5.0 & 247.2 \\
\hline
\end{tabular}

In larval surveys conducted in 1999 and 2004, no larvae were found in section P3 (Appendix 1), although suitable substratum for larvae was found there in the habitat survey carried out in 1998 (Fig. 3). Water level regulation of the reservoir was probably one of the main reasons for the absence of larvae. In late winter, just prior to the flooding period, the water level was typically lowered by $70 \mathrm{~cm}$ from the normal level. When this was coupled with a typically $50 \mathrm{~cm}$ thick ice cover, all the potential larval habitats detected in the summer must have been dewatered or compressed by the ice during late winter. Furthermore, after regulation measures the nearest spawning sites were situated as far as at the upper end of the P4.

The reasons for poor success of mitigation measures in section P4 were likely to be the substantial changes in hydrology and morphology of the river due to regulation 
measures. Because of dredging and impoundment, the riffle areas suitable for wintering of adults and spawning were lost and after impoundment the lowermost suitable areas above the Kaitfors HPP were situated at rkm 48.5. According to field observations in the embanked river section ( $\mathrm{rkm} 42-46)$, previously the best larval production site, the area of larval habitats had decreased dramatically in the few years after regulation measures and the increased erosion due to elevated current speed during flood period was suggested to be the primary reason for that (Ojutkangas et al. 1995). A more detailed habitat survey in 1998 showed that there were no broad depositional areas, but some larval habitat was left in the steep river banks (Fig. 3). As in section P3, potential habitats were dewatered or compressed by ice in late winter due to water level regulation of the reservoir.

As the larval density in section P5 was relatively high (6.0 larvae $\left.\mathrm{m}^{-2}\right)$ before damming and the hydromorphology of that section was not impacted in any way, it was expected that mitigation measures would be successful there. Yet, the average density in samplings conducted between 1999 and 2010 was only 1 larva m-2 (Appendix 1). Although the direct transplantations to the P5 were much fewer than to other sections (Table 2), telemetry experiments revealed that at least some proportion of adults released at P4 were wintering in the fast-flowing sections of the P5 (Aronsuu et al. 2015). However, it is not known whether a too low number of spawning adults and/or stocked sub-yearlings was the main reason for low larval densities in the P5 or if some unknown factor, for example chemical leaking/contamination, has appeared after impoundment.

\subsubsection{Section above the Pirttikoski HPP (P7)}

Due to the insurmountable Pirttikoski HPP and a dam built in the 1920s, there were no river lamprey larvae in section P7 (rkm 63-93) before the 1980s. Approximately 15000 adult lampreys were translocated into this section in 1989 and a total of 10000 adults in three years in the 2000s (Table 2). However, stocking of sub-yearling larvae was the main measure adopted to reintroduce river lamprey to the section P7. Approximately 98 million sub-yearling larvae were stocked into the multiple riffle areas in section P7 in 2000-2010 (Table 3). The main stocking site was at $\mathrm{rkm} 73$ where approximately 22 million larvae were stocked in 2001-2010. In the P7, the density of larvae older than one year has been surveyed only twice in the slow-flowing section below the main stocking site. The average larval densities in the study section in 2004 and 2010 were 3.0 and 0.7 larvae $\mathrm{m}^{-2}$, respectively. Densities were low compared to the densities found in the slightly regulated rivers with natural reproduction (Mäenpää 2002) or larval densities in sections P2 and P4 before regulation measures (Appendix 1). Based on restricted data on larval densities, it seems possible that the number of stocked sub-yearling larvae (average 5.2 million a year) may have been far too low to fill the larval habitats. Yearly stocking of a few million subyearling larvae to the Latvian River Daugava and its tributaries has also been suggested to be insufficient to rehabilitate lamprey population significantly (Birzaks and Abersons 2011).

\subsubsection{The River Ullavanjoki tributary}

After construction of the Kaitfors dam, adult river lampreys have not been able to migrate to the River Ullavanjoki, tributary of the River Perhonjoki, flowing into the reservoir 
(Appendix 1). It is possible that some translocated individuals have migrated downstream from the section P4 to the reservoir and then to the River Ullavanjoki. Nevertheless, it is likely that natural reproduction of river lamprey in the River Ullavanjoki has been negligible since 1983.

The reintroduction of river lamprey to the River Ullavanjoki was based only on the stocking of sub-yearling larvae, of which 73 million individuals were stocked in 1997-2010 (Appendix 1, table 3). The larval densities in the slow-flowing river section below the main stocking area, where approximately 25 million sub-yearling larvae were stocked in 19992010, varied between 9.6 and 11.9 larvae $\mathrm{m}^{-2}$ in 2004-2010 (Appendix 1). The results imply that stocking of sub-yearling larvae with an annual average of 2 million individuals in one riffle section can generate larval densities in a one kilometer section below the stocking site typical of rivers close to natural conditions (Mäenpää 2002) and of the best sites in the River Perhonjoki before major regulation measures. As the River Ullavanjoki is considerably smaller than the other rivers studied, the possibility of the existence of brook lamprey (L. planeri) is higher than in the other rivers. Therefore, the possibility of at least some proportion of the larvae being brook lampreys cannot be ruled out. Unfortunately, no larval surveys were carried out in the River Ullavanjoki before stocking was initiated.

As the proportion of L. planeri larvae is unknown and larval densities were surveyed only below the main stocking site, the number of migrating transformers is a better indicator of the success of stocking into the River Ullavanjoki than larval densities. According to the rough estimates from the drift net studies, the annual number of transformers migrating from the River Ullavanjoki in 2002-2005 varied between 10000 and 16000 with an average of 13000 individuals (Fig. 4). When compared to the average number of stocked larvae (1997-2001), approximately 2500 transformers emigrated from the river for every million stocked sub-yearlings (1/400).

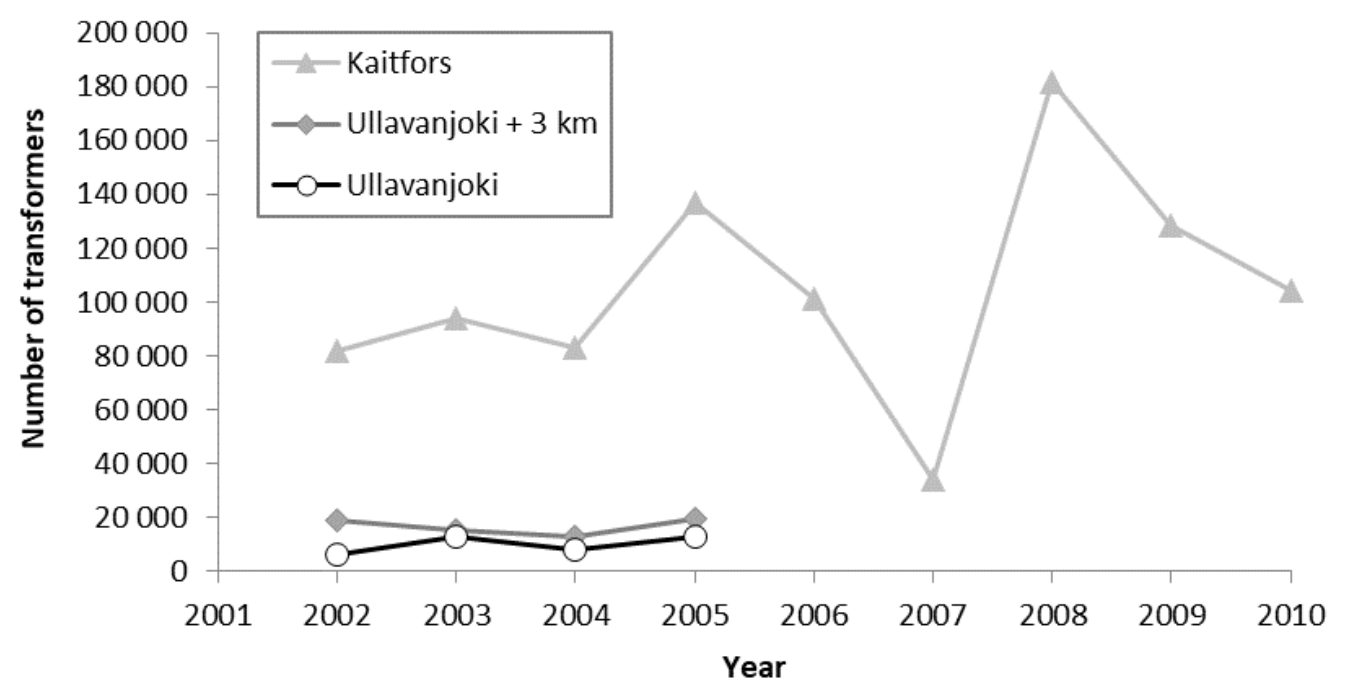

FIGURE 4 Estimated number of river lamprey transformers migrating downstream from the River Ullavanjoki (Ullavajoki and Ullavanjoki $+3 \mathrm{~km}$ ) in 2002-2005 and from the sections P3-P7 from the River Perhonjoki (Kaitfors). Note that the estimates, especially from the River Ullavanjoki, are rough due to limitations in the sampling method. 
Because of the many uncertainties in the method, the number of transformers is only a rough estimate, but it indicates that the yearly numbers of migrating transformers is likely to have been a couple of tens of thousands rather than a hundred thousand or more. This suggestion is supported by the results of drift netting in the outlet channel of the Kaitfors HPP (see below).

\subsubsection{Transformers emigrating from above the Kaitfors HPP}

The estimates of the number of migrating transformers passing the Kaitfors HPP indicate the total outcome of compensation measures in the River Perhonjoki above the Kaitfors HPP (P3-P7) and in the River Ullavanjoki. In 2002-2010, the average estimate of migrating transformers was approximately 100000 (range 34 000-180 000) (Fig. 4). Only a few data are available concerning the numbers of emigrating river lamprey transformers from other rivers. In the River Vääräjoki, the tributary of the River Kalajoki, the number of transformers emigrating during the trapping period in 2002 was estimated to be around one million (Aronsuu and Wennman 2012). It is probable that in its natural state the River Perhonjoki has produced several millions of transformers rather than hundreds of thousands. Yet, the results indicate that the rehabilitation measures have not been totally useless even if the expected outcomes were much higher.

\subsubsection{Enhancing passage over the Kaitfors dam}

Based on an order by the Environmental Court, the passage of fish and lampreys over the Kaitfors regulation dam was enhanced in 2005-2006. Four concrete weirs (head loss of 0.6$1.8 \mathrm{~m}$ ) built in the flood channel in the 1980s were modified by covering them with boulders (slope 1:10) and constructing natural-like fish ramps (slope 1:40, width 12-16 m) on the other side of the weirs. The upper edge of the weirs was modified so that at discharge $<1 \mathrm{~m}^{3} \mathrm{~s}^{-1}$ all water went through the fish ramps. Furthermore, a one kilometer section of the flood channel above the weirs was restored to be more suitable for diminished discharge. The purpose of these measures was to allow fish and lampreys to migrate up to the regulation dam. Finally, a fishway was constructed in the upper end of the flood channel to enable lampreys to pass the regulation dam. The total length of the fishway was $320 \mathrm{~m}$ and the total drop $5.3 \mathrm{~m}$. The lowermost $300 \mathrm{~m}$ of the fishway was natural-like, consisting of pool, glide and riffle sections. The uppermost section of the fishway $(20 \mathrm{~m})$ was a vertical-slot fish passage including five pools with a 14-19 cm drop between each pool. To enhance lamprey migration through the technical section, boulders were used as a substratum in the pools and bristles were attached to the bottom of each slot. The maximum flow velocity in the slots was $1.6-1.9 \mathrm{~m} \mathrm{~s}^{-1}$ and the flow velocity inside the bristles was estimated to be $0.7-1.0 \mathrm{~m} \mathrm{~s}^{-1}$. During the lamprey migration season until the end of September, discharge in the uppermost fishway was $0.8 \mathrm{~m}^{3} \mathrm{~s}^{-1}$ and in the flood channel $1.1 \mathrm{~m}^{3} \mathrm{~s}^{-1}$, and in October was $0.8 \mathrm{~m}^{3} \mathrm{~s}^{-1}$ in both the fishway and the flood channel. After that discharge dropped to $0.5 \mathrm{~m}^{3} \mathrm{~s}^{-1}$.

The results of the tagging experiments suggest that the arrangements to improve lamprey passage were not very successful. Not a single individual of the 100 anchortagged lampreys released at the lower end of the flood channel was caught with the trap at the upper end of the fishway and only four out of 100 tagged lampreys released just below 
the uppermost fishway $(320 \mathrm{~m})$ were caught with the trap. The results of the telemetry experiment were consistent with those of the anchor-tagging experiment. Eight out of nine lampreys did not migrate up to the upper fishway, but migrated up to fish ramps 1-3 (4 individuals), fish ramp 4 (1 individual) or the restored riffle area ( 3 individuals). One of the radio-tagged lampreys migrated rapidly to the upper end of the natural section of the upper fishway, but did not pass the technical section.

River lampreys are positively rheotactic and many studies have demonstrated that elevated freshwater flows activate their migration (e.g. Masters et al. 2006, Aronsuu et al. 2015). Furthermore, Foulds and Lucas (2013) observed that river lampreys hardly visited a fishway entrance during low flow periods, but peak flows activated them to enter the fishway. Therefore, uniform low discharge in a rather long flood channel may inactivate lampreys, which may at least in part explain the low passage efficiency.

Despite the low flow, 4 out of 9 radio-tagged lampreys passed all four fish ramps, 1 lamprey passed 3 of them and another 4 lampreys probably some of them, indicating that passage through fish ramps may not be a key factor in low passage efficiency.

Based on the tagging-experiments it is not possible to estimate passage through the $300 \mathrm{~m}$ long natural section of the uppermost fishway. As the slope of the natural section is approximately $1.5 \%$ and both flow conditions and substratum are heterogeneous, the natural section offers low velocity migration routes and suitable oral disc attachment sites. We therefore suggest that the natural section is easy to pass for river lamprey. However, the possibility that in some boulder dams the current speed is so high that it delays or even prevents lamprey migration cannot be ruled out.

Technical fishways are known to be challenging for river lamprey (Laine et al. 1998, Foulds and Lucas 2013), but bristles at the bottom of the slots have been shown to slightly enhance migration through vertical slot fishways (Laine et al. 1998). Four anchor-tagged lampreys passed the technical section, but it is not known, how many lampreys attempted unsuccessfully to pass it. The results suggest that, despite the boulder bed and bristles at the bottom of the slots, the technical section of the Kaitfors fishway is difficult to pass for river lamprey. However, the data are too limited for more detailed evaluation.

In total, the whole complex (4 weirs with fish ramps, restored channel, fishway with natural-like and technical sections) is passable for river lamprey. However, it seems that the proportion of lampreys passing it is so low that the present contribution of the fish passage complex to rehabilitating river lamprey population above the Kaitfors HPP is very limited. Furthermore, as all tagged lampreys were released in the flood channel, it is not known what proportion of lampreys entering the confluence of the HPP outlet and the flood channel are attracted to migrate to the flood channel.

\subsection{The River Kalajoki}

Nearly all fast-flowing areas in the River Kalajoki have been dredged at least once to enhance log floating and/or flood control. The intensity of dredging has varied from removing larger boulders to channelization. In section K3, a $10 \mathrm{~km} \mathrm{leg} \mathrm{(rkm} \mathrm{27-37)} \mathrm{was}$ embanked and dredged in the late 1960s. In the early 1980s, the Hamari HPP was constructed at $\mathrm{rkm} 45$ and simultaneously the passage of river lampreys above it was 
obstructed. Hydropeaking at the HPP was initiated in 1984 (Appendix 2). During the low flow periods the discharge at HPP varied typically between 2 and $25 \mathrm{~m}^{3} \mathrm{~s}^{-1}$ with 2 to 4 daily periods.

The first larval surveys were conducted in 1984-1986, but only the data from 1985 are suitable for density estimation. It is probable that larval population was not yet markedly affected by the hydropeaking in 1985, but it was to some extent affected by weakened water quality due to multiple earlier river regulation measures in the upper reaches of the river including constructing three HPPs and multiple reservoirs (Kainua and Valtonen 1980). In 1985, the average larval densities in sections K1 (rkm 0-12), K2 (rkm 12-22.5) and $\mathrm{K} 3$ (rkm 22.5-45) were 8.3, 2.6 and 3.2 larvae $\mathrm{m}^{-2}$, respectively (Appendix 2). In 1984, 1985 and 1986, the proportional occurrence in sampling points in sections K1, K2 and K3 varied from 60 to $89 \%$ (Appendix 2).

TABLE 4 The results of Kruskal-Wallis tests and pairwise comparisons (Dunn's test) studying differences in larval densities between years in particular sections and between sections in particular years in the River Kalajoki in 1985-1995 (a) and in 1999-2010 (b). For symbols, see Table 1 legend.

\begin{tabular}{|c|c|c|c|c|c|c|c|c|c|c|c|c|}
\hline \multirow{2}{*}{$\begin{array}{l}\text { River } \\
\text { section }\end{array}$} & \multicolumn{2}{|c|}{1985} & \multicolumn{2}{|c|}{1990} & \multicolumn{2}{|c|}{1991} & \multicolumn{2}{|c|}{1993} & \multicolumn{2}{|c|}{1995} & \multirow{2}{*}{$\begin{array}{c}\mathrm{p}- \\
\text { value }\end{array}$} & \multirow[t]{2}{*}{$n$} \\
\hline & sect. & years & sect. & years & sect. & years & sect. & years & sect. & years & & \\
\hline K1 & $i b$ & a $a$ & $b$ & $\because a$ & $b$ & 0 a & $\mathrm{b}$ & $\therefore$ a & $\mathrm{b}$ & $\stackrel{a}{a}$ & 0.321 & $20-26$ \\
\hline K2 & a & $b$ & a & $a \mathrm{ab}$ & a & ab & a & 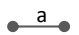 & a & $\stackrel{a}{a}$ & 0.006 & $12-16$ \\
\hline K3 & $a$ & $\mathrm{~b}$ & a & $\mathrm{a}$ & $a$ & $\mathrm{a}$ & $a$ & $\mathrm{a}$ & a & $\mathrm{a}$ & 0.001 & 26-31 \\
\hline$p$-value & $<0.001$ & - & $<0.001$ & - & $<0.001$ & - & $<0.001$ & - & $<0.001$ & - & - & - \\
\hline
\end{tabular}

\begin{tabular}{|c|c|c|c|c|c|c|c|c|c|c|c|c|}
\hline \multirow{2}{*}{$\begin{array}{l}\text { River } \\
\text { section }\end{array}$} & \multicolumn{2}{|c|}{1999} & \multicolumn{2}{|c|}{2001} & \multicolumn{2}{|c|}{2005} & \multicolumn{2}{|c|}{2007} & \multicolumn{2}{|c|}{2010} & \multirow{2}{*}{$\begin{array}{c}\mathrm{p}- \\
\text { value }\end{array}$} & \multirow[t]{2}{*}{$n$} \\
\hline & sect. & years & sect. & years & sect. & years & sect. & years & sect. & years & & \\
\hline K1 & ab & . a & $\mathrm{ab}$ & 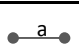 & $a \mathrm{ab}$ & $a$ & $i b$ & a $a$ & ab & $a$ & 0.231 & 10 \\
\hline K2 & a & 0 & a & $a b_{0}$ & $a b$ & $a b$ & $a b$ & ab & $a b$ & $b$ & 0.003 & 20 \\
\hline K3 & a & 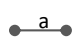 & a & $a$ & a & 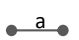 & a & 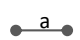 & a & . $a$. & 0.376 & 10 \\
\hline $\mathrm{V}$ & $\mathrm{b}$ &.$a$ & $\mathrm{~b}$ & . & $b$ &.$a$ & $b$ &. & $\mathrm{~b}$ &.$a$ & 0.175 & 10 \\
\hline $\mathrm{p}$-value & $<0.001$ & - & $<0.001$ & - & 0.030 & - & 0.004 & - & 0.002 & - & - & - \\
\hline
\end{tabular}

In the early 1990s, the average larval density in section K1 was still at a high level, but in the $\mathrm{K} 2$ and $\mathrm{K} 3$ it had decreased significantly, the mean density being less than 1 larva $\mathrm{m}^{-2}$ (Appendix 2, Table 4). Especially in the K3, the proportional occurrence of larvae in sampling points was also reduced markedly after the mid 1980s. Furthermore, in 1990 only $7 \%$ of larvae found from the K3 were smaller than $100 \mathrm{~mm}$, the percentage in 19851986 having been $48 \%$. This also indicated problems in reproduction in the K3 since the mid 1980s. It is likely that the negative development in larval population in the K3 was mainly due to hydropeaking at the Hamari HPP (see chapter 4.1.1.).

In the mid 1980s, larval densities in the K3 were highest in the uppermost part of the section, but in the early 1990s it was difficult to find soft bottomed areas for sampling any more. Larval habitat surveys in 1996 showed that there were only a few areas with bottoms suitable for larval lamprey in the K3, especially in the two uppermost long, slowflowing sections, where hard clay was the prevailing substratum (Fig. 5). This is likely to 
be connected to increased erosion due to hydropeaking. At the rkm 27-37, the regulation measures conducted in the 1960s may have also impacted larval habitats as dredging has decreased the amount of soft bottoms and embankment increased current speed during high flows. However, in the slow-flowing section at rkm 33.8-37.2, the habitat suitability index was higher than elsewhere in section $\mathrm{K} 3$. This was mainly due to the wide river section, where current speed was constantly low enough for eroded material to accumulate and form a large, river-wide depositional area. Also, in the lower part of the section K3, depositional areas appeared after initiating hydropeaking. Many of these depositional areas have been removed through the years on the grounds of court orders interpreting deposition as a negative consequence of hydropeaking.

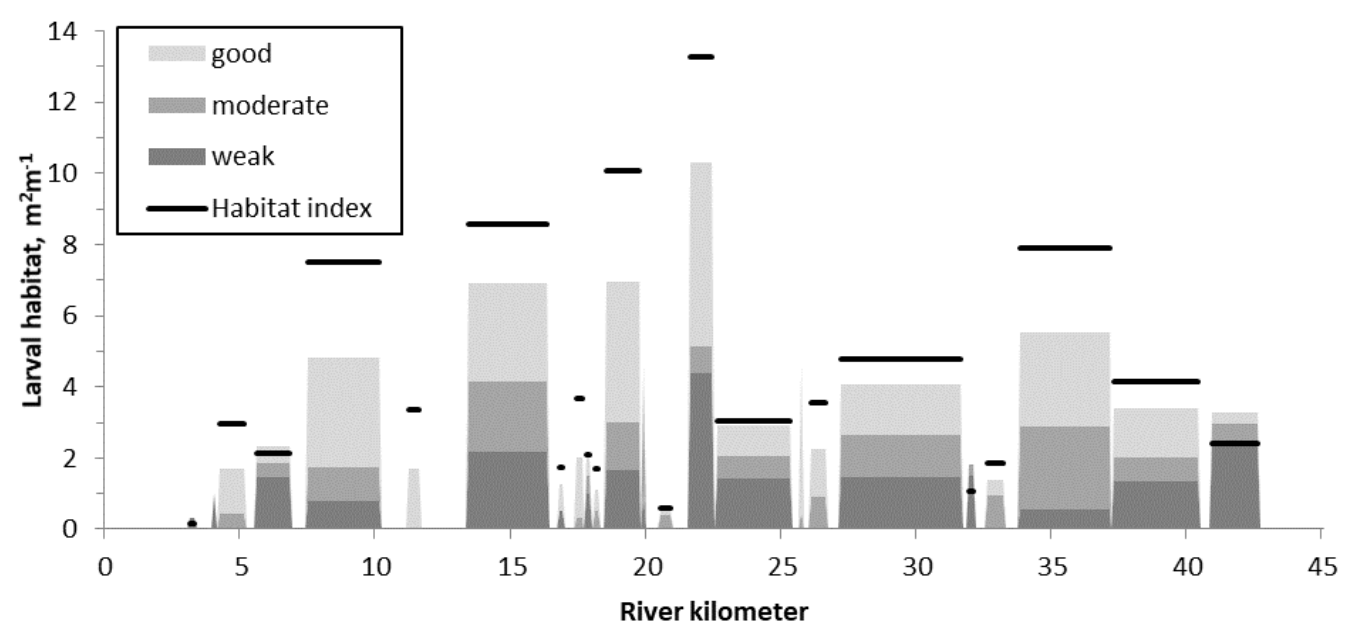

FIGURE 5 The average river lamprey larval habitat availability $\left(\mathrm{m}^{2} \mathrm{~m}^{-1}\right)$ in each continuous slowflowing section in the River Kalajoki. Habitat suitability has been divided into four categories based on substratum type and depth: a) unsuitable (not shown), b) weak, c) moderate and d) good. The rough habitat suitability index for slow-flowing sections has been calculated by weighing the estimated mean area $\left(\mathrm{m}^{2} \mathrm{~m}^{-1}\right)$ of categories $\mathrm{a}, \mathrm{b}, \mathrm{c}$ and $\mathrm{d}$ with $0,0.5,1.0$ and 2.0 , respectively and summing them.

Another massive river regulation measure took place in 1990-1992, when the lowermost part of the K3 (rkm 22.8-25.4) was intensively dredged and the Vivunkumpu weir was constructed at the rkm 22.5 (Appendix 2). In 1996, the larval habitat index in the dredged section was $3 \mathrm{~m}^{2} \mathrm{~m}^{-1}$, but in the $1 \mathrm{~km}$ section below it (rkm 21.4-22.5) it was $13 \mathrm{~m}^{2} \mathrm{~m}^{-1}$ (Fig. 5). Before dredging these sections were judged very similar. Thus, dredging had reduced larval habitat markedly (at least temporarily).

A vertical-slot fishway was built on the north side of the Vivunkumpu weir in 1992. Monitoring revealed that fish had problems in finding and passing the fishway and the current speed in the fishway was too high (up to $>2 \mathrm{~m} \mathrm{~s}^{-1}$ ) for lamprey (Aronen 1998). Therefore, it is likely that the majority of the lampreys reaching the Vivunkumpu weir were unable to pass the weir, and this further accelerated the collapse of larval abundance in section $\mathrm{K} 3$ and consequently, the average larval densities in all sampling occasions in 1993-2007 were less than 0.3 larvae $\mathrm{m}^{-2}$ (Appendix 2). 
The regulation measures carried out in 1990-1992 in the lower end of the K3 also had an effect downstream, because dredging increased the content of suspended sediments in the river water markedly down to the estuary (Aronen 1995). Poor water quality due to dredging in the early 1990s may have increased the mortality of wintering adults and larvae in section K2 and possible directed upstream migrating lampreys to migrate to the River Vääräjoki and further reduced larval density, which may have already earlier been affected by hydropeaking. In 1993, 1995 and 1999 the average larval density in the $\mathrm{K} 2$ was less than 0.3 larvae $\mathrm{m}^{-2}$ (Appendix 2). Habitat surveys in 1996 indicated that the state of larval habitats in K2 was better than in section K3 (Fig. 5) suggesting that erosion due to hydropeaking may have not seriously damaged them. However, it is possible that wintering, spawning and early stages of lamprey were impacted by hydropeaking. It is not known, if the poor water quality in the winters 19901992 or hydropeaking was the main reason for low larval densities in the K2 in the early 1990s (Appendix 2, Table 4).

When the larval densities above rkm 12 (K2 and K3) reduced markedly after the mid 1980s (Appendix 2), also the concentration of migratory pheromones released by larvae (Fine et al. 2004) decreased. We hypothesize that this may have led to a negative feedback loop as higher proportion of upstream migrating adult lampreys than earlier may have migrated to the River Vääräjoki, where the concentration of migratory pheromones must have been much higher than in the main channel above rkm 12, because of higher larval density (Aronsuu and Wennman 2012, Appendix 2) and lower discharge than in the main channel. This probably decreased larval production further in the main channel above rkm 12. This kind of feedback loop between adult lamprey migration and larval density has not been shown among river lamprey, but it has been suggested to be important for sea lamprey (e.g. Neeson et al. 2011, Meckley et al. 2012).

In section $\mathrm{K} 1$, the development of larval densities differed from that of the section $\mathrm{K} 2$ and K3. In 1985-1995, excluding 1991, the average larval density of sampling points was higher (8-12 larvae $\left.\mathrm{m}^{-2}\right)$. There are three potential explanations for that:

1) Because of the longer distance to the source of hydropeaking and dredging, the negative effects in $\mathrm{K} 1$ have been milder.

2) The River Vääräjoki, the main tributary of the River Kalajoki, enters the upper end of the section $\mathrm{K} 1$ ( $\mathrm{rkm}$ 9). When coupled with the facts that lampreys are migrating downriver during their larval stage (Potter 1980) and according to the larval densities (Appendix 2) and the number of emigrating transformers (Aronsuu and Wennman 2012) the larval production in the River Vääräjoki is likely to be quite high. It is probable that larvae drifting from the River Vääräjoki contribute markedly to larval densities of the section $\mathrm{K} 1$.

3) Only one long slow-flowing section exists in section K1 (Fig. 5). Before 1999, 3/4 of the sampling points were situated in the fast-flowing sections or in the short slow-flowing sections. Typically the quality of the larval habitats in these sections is good, but their area is small and larvae are concentrated in the patches with small areas. Since 1999, all sampling points were situated in the only long slow-flowing section containing 
approximately $70 \%$ of the potential larval production areas of the $\mathrm{K} 1$, and they may have indicated the state of larval population in section K1 more reliably.

When the sampling protocol in 1999 was changed, the estimated average density in section $\mathrm{K} 1$ dropped to only 1.3 larvae $\mathrm{m}^{-2}$ (Appendix 2). In the slow-flowing section, where the sampling sites were situated (rkm 8-10) the ice cover was typically markedly thicker than in most of the other slow-flowing sections below the Hamari HPP and there were frequent large ice jams (Savolainen and Leiviskä 2008). These ice phenomena are partly due to natural hydromorphology of the river, but hydropeaking was suggested to have intensified them (Savolainen and Leiviskä 2008). It is also possible that channelization of the long riffle section above the slow-flowing section has delayed formation of stable ice cover and consequently increased formation of fragile ice and hanging dams, which have further thickened the ice cover in the slow-flowing section. As described earlier, thickened ice cover compresses and freezes larval habitats and when it moves up and down due to fluctuating flow erosion increases. Furthermore, hydraulic force during ice jams and break-up along with the mechanical effects of moving ice blocks can severely erode channel beds (Prowse and Culp 2003).

In 1997, the court ordered to improve reproduction potential of lamprey and crayfish (Astacus astacus) by restoring the River Kalajoki. Based on the order, all the fastflowing river sections (55 ha) of the lowermost 33 kilometers were restored in 2001-2003. In addition to conventional restoration methods described earlier, some tailored methods to restore habitats for lamprey and crayfish were introduced. Besides the active augmentation of 8-40 mm gravel into nearly all riffle sections, gravel beds for lamprey spawning were restored with two other methods. In 2002 and 2004, altogether $300 \mathrm{~m}^{3}$ of natural gravel $(\approx 1-50 \mathrm{~mm})$ from a gravel pit were dumped down the stream bank and into the channel in three locations (rkms 2.5, 10.7, 16.7), just above newly restored long riffle sections. Later, during the spring flood gravel was carried downstream by the flood. The third method for restoring spawning gravels was to construct gravel beds out of natural gravel found under boulder piles while restoring riffles. Gravel was not transferred to other locations, but the morphology of the channel was manipulated so that the current speed and the water depth of gravel beds were assumed to be suitable for lamprey. Boulders suitable for attachment were also placed in the gravel beds. If gravel was embedded, it was cleaned by rinsing with flowing water using an excavator. In run and glide sections, in addition to conventional restoring methods, piles of boulders and cobbles were added to the river, whenever extra material was available. The main goal was to increase shelter structures for crayfish, but boulder piles were also offered as wintering habitats for adult lamprey (Aronsuu et al. 2015).

No sub-yearling larvae were detected below the two intensively dredged riffles in the $\mathrm{K} 1$ and $\mathrm{K} 2$ before the restoration was completed, but after restoration sub-yearling larvae started to appear in the sampling sites below both riffles (Table 5) suggesting that restoration might have enhanced reproductive success. In the 2000s, also the densities of larvae older than one year increased in the long slow flowing sections of the K1 and K2 (Appendix 2), thus supporting the previous suggestion. Due to the small number of sampling sites and patchy distribution of larvae the results of statistical testing did not give much insight into data interpretation (Table 4). Compared to the year 1999 density 
was significantly higher only in the K2 in 2010 when the mean density (3.1 larvae $\mathrm{m}^{-2}$ ) was over ten times higher than the density in 1999 and earlier in the 1990s (Appendix 2). Nevertheless, we suggest that the size of larval population in the K1 and K2 may have increased markedly in the 2000s. This increase cannot, however, be linked definitely to restoration. First of all, in the K2 larval densities were at an elevated level already in 2001 when the first restoration measures were performed indicating that there were also other factors in addition to restoration promoting positive development in larval densities. For example, as a consequence of the increase in larval densities in section $\mathrm{K} 2$ in the early 2000s, the release of migratory pheromones must have increased as well, which might have created a positive feedback loop, opposite to that suggested to have occurred in the 1990s. Thus, the proportion of adults selecting the main channel as a migration route instead of the River Vääräjoki may have increased.

TABLE 5 The number of sub-yearling larvae per 250 tube samples (in total $\approx 9 \mathrm{~m}^{2}$ ) below three riffle areas in the Rivers Kalajoki and in the control sites in the Rivers Vääräjoki and Siiponjoki in 2000-2010.

\begin{tabular}{lrrrrrrrrrr}
\hline \hline Sampling site & \multicolumn{10}{c}{ Number of sub-yearling larvae / 250 tube samples } \\
\cline { 2 - 11 } & 2000 & 2001 & 2002 & 2003 & 2005 & 2006 & 2007 & 2008 & 2009 & 2010 \\
\hline Kalajoki (rkm 10) & 0 & 0 & 0 & 6 & 24 & 2 & 0 & 7 & 18 & 25 \\
Kalajoki (rkm 16) & 0 & 0 & 0 & 3 & 24 & 4 & 3 & 1 & 22 & 56 \\
Kalajoki (rkm 42) & 0 & 0 & 0 & 0 & 0 & 0 & 0 & 0 & 3 & 1 \\
Siiponjoki (cont.) & - & 275 & 188 & 58 & 158 & 393 & 53 & 30 & 108 & 130 \\
Vääräjoki (cont.) & - & 325 & 0 & 5 & 60 & 45 & 0 & 40 & 245 & 10 \\
\hline \hline
\end{tabular}

Hydropeaking at the Hamari HPP was slightly mitigated during the study period. From the mid 1980s to the early 2000s discharge at the Hamari HPP fluctuated typically from 2 to $25 \mathrm{~m}^{3} \mathrm{~s}^{-1}$. In 1997, the court ordered to add a flow period during the night if necessary to reduce the water level fluctuation. Furthermore, in 2004 hydropeaking was mitigated on the voluntary basis by the owner of the Hamari HPP. Since then, especially during the low flow periods, maximum discharges and duration of minimum discharge periods have decreased to some extent. Therefore, positive changes in flow regime and ice conditions due to mitigation of hydropeaking may have improved habitats of lampreys in different life stages.

In the K3, three dredged short riffles between rkms 31 and 33 were restored in 2003 to enhance lamprey and fish habitats, but at that time Vivunkumpu weir still seriously hampered migration of lampreys up to the section K3 (Appendix 2). In the mid 2000s, the passage of local fish species and lamprey over the Vivunkumpu weir was improved by covering the concrete weir with boulders so that the slope of the downstream end was 1:10. Moreover, after numerous meetings with the local fishermen, two fishways side by side were constructed at the north side of the weir. A Super-active baffle (Larinier) fishway (width $1.2 \mathrm{~m}$, slope 1:10) was built beside the river bank. A rampart separated the natural-like fish ramp from the technical fishway. The width of the fish ramp was $15 \mathrm{~m}$ and its total length approximately $50 \mathrm{~m}$. The upper end of the fish ramp was approximately $20 \mathrm{~m}$ above the weir. The fish ramp had five bars made of big boulders, but boulders of all sizes were added in the bars and in the pools between them to create a heterogenic substratum structure and flow conditions. When the discharge was less than $15 \mathrm{~m}^{3} \mathrm{~s}^{-1}$, all the water discharged through the fish ramp and technical fishway. When 
discharge rose above $15 \mathrm{~m}^{3} \mathrm{~s}^{-1}$, the water started to gradually run also over the other part of the weir with a total width of $100 \mathrm{~m}$. The fishways were constructed in 2005, but the natural-like fishway was modified in 2006 and 2007.

In the telemetry experiment, all 10 radio-tagged lampreys selected the fish ramp instead of the technical fishway and passed the weir via it; seven of them during the first night after release $350 \mathrm{~m}$ below the weir (for details see Aronsuu et al. 2015). The high flow through the fish-ramp may have lured lampreys to select it and, therefore, the suitability of the super-active baffle fishway for lamprey remained unknown. However, the results suggest that the fish ramp enabled adult lampreys to migrate to the section K3.

In 2010, the average larval density in section K3 was as low as 0.7 larvae $\mathrm{m}^{-2}$ and the proportional occurrence of larvae only $30 \%$ indicating that the opening of the migration route did not alone markedly enhanced the larval population, at least in the upper part of the section K3, where sampling sites were situated. Hydropeaking was obviously still a problem, and furthermore, the longest riffle area ( $\mathrm{rkm} \mathrm{42.6-43.4)} \mathrm{in} \mathrm{the} \mathrm{K3} \mathrm{was} \mathrm{entirely}$ modified in 2004-2005 to reduce the water level fluctuation and ice problems due to intensive hydropeaking. The riffle was totally dredged and five block stone weirs were constructed. In 2002-2008, no sub-yearling larvae were found below the riffle area, but in 2009 three and in 2010 one individuals were found (Table 5), which demonstrates that at least some lampreys were able to spawn in this morphologically and hydrologically severely impacted environment.

In the K3, the proportion of fast-flowing sections was naturally low and the river engineering measures in the 1990s and 2000s decreased it further. Approximately $80 \%$ of the total drop of the $\mathrm{K} 3(15 \mathrm{~m})$ was in the block stone weirs and the only natural-like fastflowing sites were situated at $\mathrm{rkm} 31-33$ in three short riffle areas. As larval densities below rkm 34 have not been studied, it is not known, if the reproduction in the small restored riffles at $\mathrm{rkm} 31-33$ has been more successful than in the upper end of the section K3.

The number of adults entering the River Kalajoki decreased significantly during the study period (linear trend, $\mathrm{p}<0.006$, Appendix 2). In the 1980s the average number was 340000 whereas in the 2000s it was 220 000. The average fishing mortality in 1980s was as high as $53 \%$, but it has decreased slightly being $46 \%$ in 2000 s (linear trend, $p=0.18$ ). The escapement has decreased (negative linear trend, $p=0.042$ ), but as the fishing mortality has decreased simultaneously, the proportional decrease in escapement has been less than that in the initial number entering the river.

The larval densities in the river Kalajoki, especially in sections K2 and K3 collapsed in the 1980s and were at a very low level in the 1990s when the escapement was at a similar or even higher level than in the 2000s, when the larval densities in the K1 and K2 increased and stayed at the elevated level. This suggests that the escapement and consequently the number of spawning adults have not regulated the larval production in the 1980s and 1990s, but some anthropogenic pressures other than fishing have caused the decrease in the larval densities in the 1980s and 1990s. However, the proportion of escapement that has migrated to the River Vääräjoki tributary for spawning is unknown and therefore the possibility that the decrease in larval densities in the 1990s in the K2 was partly due to a too small number of spawning adults cannot be ruled out. 
It seems that in the 2000s the conditions in the River Kalajoki for larval production have improved while the time series supports with lowest risk of error the conclusion that the escapement has declined. Consequently, the precautionary principle requires that ensuring a sufficient spawner number for normal larval production must be one of the main concerns in lamprey fisheries management. Quantifying the "sufficient" and "normal" number obviously requires more thorough studies on lamprey reproduction regulation. Meanwhile, the local fisheries associations in the River Kalajoki have adopted a precautionary policy by voluntarily restricting their fishing pressure e.g., in the beginning of the 2000s fishermen had approximately 80 fyke nets in use in the estuary while the number in 2009 and 2010 was only 45. 


\section{LESSON LEARNT}

\subsection{Translocations}

In the River Perhonjoki, the translocations of adult lampreys poorly compensated the negative impacts of regulation measures. It is likely that there were many reasons for that: too few translocated adults, their abnormally high mortality due to increased predation risk during wintering, and the degradation of habitats of different life stages. The results clearly demonstrate that translocations will not automatically compensate for the negative effects of obstructed migration and underline the importance of monitoring the results of translocations. In the future, one of the most important goals is to better understand, which are the key factors causing the low success and then finding ways to minimise their effect. The success of translocations of Pacific lamprey in the upper reaches of the Umatilla River has demonstrated that even a low number of translocated adults (annual average 370 ind.) are capable of producing high larval densities, if habitats are close to their natural stage (see Close et al. 2009). However, in the lower reaches of the Umatilla River, where anthropogenic disturbances were more severe, larval densities did not rise after translocations (Close et al. 2009).

Translocation of adult lampreys is a mandatory measure also in the large regulated Rivers Oulujoki, Iijoki and Kemijoki, flowing into the Bothnian Bay (Fig. 1). Annually, 50 000, 60000 and 100000 adults, respectively, are released above migration barriers during autumn migration (Hiltunen et al. 2013). Since the mid 1980s, most of the adult lampreys have been released into the severely short-term regulated impoundments between the HPPs with none or only a few small tributaries entering them (Hiltunen et al. 2013). In recent years, lampreys have also been translocated to the tributaries of the Rivers Iijoki and Oulujoki and in the River Iijoki to the main channel above the impounded river section approximately at rkm 60 (Hiltunen et al. 2013).

The effectiveness of these translocations has not been assessed properly. They have been assumed to be sufficient mainly because enough lampreys enter the rivers year after year for carrying out the translocations (M. Huolila and K. Koivisto, regional fisheries authorities in Kainuu and Lappi, respectively, pers. com.). Based on the impacts of river modification and hydropeaking on lampreys in the rivers Perhonjoki and Kalajoki, it 
seems possible that the efficacy of translocations in the formerly mentioned three rivers have been low. Furthermore, an unknown number of lampreys try to migrate into these rivers, but migration is obstructed by the lowermost dams facing estuaries. As the outflow of these three rivers is approximately $50 \%$ of the total flow into the Bothnian Bay from Finland, they may attract a substantial proportion of lampreys of the Bothnian Bay (see Aronsuu et al. 2015) and in the worst scenario they may be serious ecological traps (see e.g. Delibes et al. 2001, Battin 2004) for the lamprey population of the Bothnian Bay like the River Daugava may be for the population of the Gulf of Riga (Birzaks and Abersons 2011). Therefore, it would be important to understand the effectiveness of the translocations as well as the number and destiny of lampreys entering these rivers.

\subsection{Stocking of sub-yearling larvae}

Compared to transplantations of adults, stocking of sub-yearling larvae is more time and labour consuming. It consists of purchasing adult lampreys and holding them through winter, spawning them manually, incubating eggs, rearing prolarvae until they are capable of constructing a burrow and finally stocking them. Even though our data is limited, it implies that in the main channel of the River Perhonjoki, the number of stocked sub-yearling larvae has not been sufficient in respect to the area for which the stockings should have established larval densities comparable to those in natural rivers with natural reproduction. Based on rough estimates of fecundity (15 000) and egg mortality (50\%), only 2000 females in natural conditions are needed to produce the number (15 million) of larvae that has been stocked yearly in two rivers. Furthermore, it is likely that the mortality of stocked larvae is higher than that for larvae hatched in the river. This is because unavoidably, a certain proportion of larvae must be stocked before they are capable of constructing a burrow to protect themselves from predation (see Aronsuu and Virkkala 2014). Occasionally the condition of reared larvae has not been the best possible, which has also decreased the outcome of stockings to some extent. If methods for rearing larvae for a longer time before stocking were developed, it would most likely increase the survival of stocked larvae. However, we have found longer rearing ineffective, because with the present rearing methods the risk of high mortality increases after individuals have reached the mean size of $7 \mathrm{~mm}$.

Evidently, the stocking of sub-yearling larvae is an applicable method for reintroducing lamprey population to the area where it has disappeared and currently cannot naturally migrate. Translocation of adults is obviously another option for that, but the stocking of sub-yearling larvae is likely to be a better option, if the availability of adults is restricted or their wintering and/or spawning circumstances are for some reason poor. However, in the long run the above-mentioned problems should be solved and the stockings of sub-yearling larvae should be substituted with translocations of adults and above all, whenever possible, natural migration to the spawning sites should be enabled. We do not see the stocking of sub-yearling larvae as a sustainable solution for rehabilitating lamprey populations. 


\subsection{Hydropeaking}

According to our results, hydropeaking is detrimental for river lamprey populations and in boreal climate the negative effects on lamprey habitats are pronounced due to negative changes in different ice phenomena. The harmful effects can be mitigated by morphological structures, but mitigation of the hydropeaking itself is likely to be one of the key factors in rehabilitating lamprey populations in short-term regulated rivers. Morphological improvements are useless if the flow regime is not within the acceptable range (e.g. Weber et al. 2007).

The prohibition of hydropeaking during early summer in the River Perhonjoki may have improved circumstances for spawning, embryonic development and for prolarvae, but the river lamprey population is still impacted by many anthropogenic pressures, including hydropeaking during other times. Probably therefore, no positive effect could be detected in larval densities. In the River Kalajoki, slight mitigation of hydropeaking may have improved the effect of restoration.

More studies are needed to better understand how hydropeaking affects different life stages of river lampreys and how to cost-effectively mitigate hydropeaking to improve lamprey populations.

\subsection{River restoration}

Dredging, channelization and embankment have deteriorated habitats of river lamprey and may intensify the negative effects of hydropeaking. Therefore restoration measures are needed in re-establishing lamprey populations.

In the River Kalajoki, the increase in both the abundance of sub-yearling larvae and the densities of larvae older than one year may be attributable to the restoration of fastflowing sections with lamprey-specific methods. In the lower end of the River Perhonjoki, conventional restoration measures have not increased larval density. It is probable that in the River Perhonjoki other factors such as hydropeaking, poor water quality and partly also channelization of slow-flowing area limited larval densities and therefore positive impacts were not obtained. In addition, the restoration methods were partly different from those used in the River Kalajoki.

There are various possible mechanisms how restoration of fast-flowing sections may increase larval densities. Restoration may enhance the survival of wintering adults by increasing the number of potential wintering sites like boulder piles and other instream structures (Aronsuu et al. 2014) and by reducing the negative effects of hydropeaking. Restored riffles may get permanent ice cover earlier (Lind and Nilsson 2014) than dredged ones and consequently they are more stable habitats e.g. formation of anchor ice may have diminished. However, the effect of restoration is site specific and it may also increase anchor ice formation (Lind and Nilsson 2014). Furthermore, constructed boulder dams and cobble ridges reduce the water level fluctuation caused by hydropeaking, which may diminish the mortality of eggs and prolarvae. Also, reproduction may improve due to a marked increase in gravel bottom habitats suitable for spawning, egg incubation and 
prolarvae. The restoration of fast-flowing sections may decrease erosion in larval habitats by decreasing the frazil float and the formation of hanging dams (see Huusko et al. 2013) and also the water flow above the ice cover, and consequently, the thickness of the ice cover in slow-flowing areas is likely to decrease. However, the effects of restoration of fastflowing areas on lamprey populations are still speculative and more research is needed.

The experimental restoration of a channelized slow-flowing river section for improving larval habitats by widening the river and constructing small bays was not successful, but the method is still worth developing. In the future, better planned and probably more radical measures are needed to create suitable larval habitats in channelized river sections affected by hydropeaking.

\subsection{Fishways}

Small-scale barriers, even gauging weirs (Russon et al. 2011), may impede upmigration of river lampreys, and most types of technical fishway types have been found to be challenging for them (Laine et al. 1998, Foulds and Lucas 2013). The results from the River Kalajoki suggest that a natural-like fish ramp is an appropriate solution to enhance passage of river lampreys over low-head barriers. Similar fish ramps were constructed in the flood channel of the River Perhonjoki and lampreys were able to pass them.

To make lampreys pass higher obstructions is a much more difficult task. Naturallike fishways are assumed to be suitable for most fish species. However, it seemed that too low flow in the natural-like section of the fishway complex passing the Kaitfors dam did not activate the migration of lampreys. In future, the effects of flow pulses should be tested to see if they activate lampreys to pass the natural-like section. Furthermore, it should be more accurately evaluated, whether the other sections of the fishway complex impede migration and after that it should be planned how the sections should be modified. The long-term goal should be to improve structures and flow patterns of the fish ways and eventually improve passing efficiency so that transplantations of adults and stockings of larvae could be stopped.

\subsection{Fishing mortality}

Fishing mortality in both rivers was high even though it decreased during the study period. Furthermore, the number of adult lampreys entering the rivers decreased over time. Yet our results suggest that so far the larval densities have varied independently of the escapement suggesting that the dynamics of reproduction output has been mostly driven by other factors than the abundance of spawning stock. Nevertheless, according to the precautionary approach of responsible fisheries management (Anon. 1995), it must be taken as a starting point that the data supported the conclusion that there was a declining trend in escapement in both rivers, and thus measures to prevent any further decline must be adopted soon. Furthermore, in the 2000s the environmental circumstances for lamprey reproduction, especially in the River Kalajoki, have improved due to mitigation measures. 
Therefore, the spawning stock size can be expected to increasingly regulate the reproduction potential. Thus, the regulation of fishing mortality should be included in the tool box for the rehabilitation of lamprey populations. Fisheries associations in the River Kalajoki and in many other rivers in Finland have had the foresight to adopt a precautious fishing policy of voluntarily restricting their lamprey fishing (Hiltunen et al. 2013).

\subsection{Finally}

In the River Perhonjoki, the monitoring results were used according to the principles of adaptive management (Holling 1978) to continuously develop ways to rehabilitate lamprey populations based on the accumulating knowledge. Furthermore, some studies on the ecology of river lamprey were carried out to support this work (Aronsuu and Virkkala 2014, Aronsuu et al. 2015, Aronsuu and Tertsunen 2015, Mäenpää et al. 2002, Myllynen et al. 1997). However, our understanding was not adequate enough when we had to make suggestions for changes in the mandatory compensation measures for the Environmental Court. In hindsight, as this work was done mostly in the role of a permit holder with limited resources, we were in the situation to bite off more than we could chew. Nevertheless, the problem of high uncertainty involved when assuming that the court-stipulated compensation measures are adequate in certain specific place and time, is typical. Obviously this uncertainty is particularly pronounced when untested compensation measures are applied to enhance populations of species with a poorly known and complex life history in the area affected simultaneously by various anthropogenic pressures.

In the future, ELY Centres as permit holders should improve the monitoring programs and the ways to carry out the compensation measures to gain more reliable evidence on the success of different measures. To this end, it would be important that also other permit holders ordered to monitor the success of compensation measures would do their share closely guided by the regional fisheries authorities. As research work in ELY Centres has been terminated, monitoring will be carried out by private consultant companies in the future. The logical choice for the agent taking responsibility of the research and method development concerning conservation and rehabilitation of river lamprey populations in Finland is Natural Resources Institute Finland supported by the universities.

\section{ACKNOWLEDGEMENTS}

We are grateful to all the field workers for their effort and local lamprey fishers for providing us with fishing effort and catch statistics. We also thank Dr. Martyn C. Lucas and Dr. Lea Hiltunen for their valuable comments on the manuscript and professor Roger I. Jones for checking the language. 


\section{REFERENCES}

Almeida P.R. \& Quintella B.R. 2002. Larval habitat of the sea lamprey (Petromyzon marinus L.) in the River Mondego (Portugal). In Collares-Pereira M.J., Coelho M.M. \& Cowx I.G. (eds), Freshwater fish conservation: options for the future, Fishing News Books, Blackwell Science, Oxford, pp. 121-130.

Anon. 1995. Code of conduct for responsible fisheries. FAO, Rome.

Aronen K. 1995. Kalajoen kalataloudellinen tarkkailu-tutkimus 1990-1992 - Alavieskan tulvasuojelutöiden vaikutukset kala-, nahkiais- ja rapukantoihin. Vesi- ja ympäristöhallituksen monistesarja 456: 1-68.

Aronen K. 1998. Kalajoen alaosan kalataloudellinen tila vuosina 1995-1997. Alueelliset ympäristöjulkaisut 79: 1-98.

Aronsuu K. \& Tertsunen J. 2015. Selection of spawning substratum by European river lampreys (Lampetra fluviatilis) in experimental tanks. Mar. Freshw. Behav. Phy. 48: 4150.

Aronsuu K. \& Virkkala P. 2014. Substrate selection by sub-yearling European river lampreys (Lampetra fluviatilis) and older larvae (Lampetra spp). Ecol. Freshw. Fish 23: 644-655.

Aronsuu K. \& Wennman K. 2012. Vesirakentamisen ja säännöstelyn sekä niihin liittyvien kompensaatio-toimenpiteiden vaikutukset Kalajoen kala-, nahkiais-, ja rapukantoihin: Yhteenveto vuosien 1978-2010 velvoitetarkkailuiden tuloksista. Pohjois-Pohjanmaan ELY-keskus. Elinvoimaa alueelle 5/2012: 1-82.

Aronsuu K., Marjomäki T.J., Tuohino J., Wennman K., Vikström R. \& Ojutkangas E. 2015. Migratory behaviour and holding habitats of adult river lampreys (Lampetra fluviatilis) in two Finnish rivers. Boreal Env. Res. 20: 120-144.

Aroviita J. \& Hämäläinen H. 2008. The impact of water-level regulation on littoral macroinvertebrate assemblages in boreal lakes. Hydrobiologia 613: 45-56.

Battin J. 2004. When good animals love bad habitats: Ecological traps and the conservation of animal populations. Conserv. Biol. 18: 1482-1491.

Beamish F.W.H. \& Jebbink J. 1994. Abundance of lamprey larvae and physical habitat. Environ. Biol. Fish. 39: 209-214.

Birzaks J. \& Abersons K. 2011. Anthtropogenic Influence on the Dynamics of the River lamprey Lampetra fluviatilis Landinds in the River Daugava Basin. Scientific Journal of Riga technical University 7: 32-38.

Bracken F.S.A. \& Lucas M.C. 2013. Potential impacts of small-scale hydroelectric power generation on downstream moving lampreys. River Res. Appl. 29: 1073-1981.

Close D.A., Fitzpatric M.S. \& Li H.W. 2002. The ecological and cultural importance of species at risk of extinction, pacific lamprey. Fisheries 27: 19-25.

Close D.A., Currens K.P., Jackson A., Wildbill A.J., Hansen J., Bronson P. \& Aronsuu K. 2009. Lessons from the reintroduction of a noncharismatic, migratory fish: Pacific lamprey in the upper Umatilla River, Oregon. In Brown L.R., Chase S.D., Mesa M.G., Beamish R.J. \& Moyle P.B. (eds), Biology, management, and conservation of lampreys in North America, American Fisheries Society, Symposium 72: Bethesda, Maryland, pp. 233-254. 
Delibes M., Gaona P. \& Ferrera P. 2001. Effects of an attractive sink leading to maladaptive habitat selection. Am. Nat. 158: 277-285.

Elosegi A. \& Sabater S. 2013. Effects of hydromorphological impacts on river ecosystem functioning: a review and suggestions for assessing ecological impacts. Hydrobiologia 712: 129-143.

Fine J.M., Vrieze L.A. \& Sorensen P.W. 2004. Evidence that Petromyzontid lampreys employ a common migratory pheromone that is partially comprised of bile acids. $J$. Chem. Ecol. 30: 2091-2110.

Fogelin P. 1972. Studier över drift av larver och nymetamorfoserade ungar av flodnejonöga (Lampetra fluviatilis L.) i Indalsälven och Rickleån. Rapport från Rickleå fältstation 20: 1-28.

Foulds W.L. \& Lucas M.C. 2013. Extreme inefficiency of two conventional, technical fishways used by European river lamprey (Lampetra fluviatilis). Ecol. Eng. 58: 423-433.

Foulds W.L. \& Lucas M.C. 2014. Paradoxical Exploitation of protected fishes as bait for anglers: evaluating the lamprey bait market in Europe and developing sustainable and ethical solutions. Plos One 9(6): e99617.

Gamper N. \& Savina M.V. 2000. Reversible metabolic depression in hepatocytes of lamprey (Lampetra fluviatilis) during pre-spawning: regulation by substrate availability. Comp. Biochem. Physiol. 127: 147-154.

Garcia X. F., Schnauder I. \& Pusch M.T. 2012. Complex hydromorphology of meanders can support benthic invertebrate diversity in rivers. Hydrobiologia 685: 49-68.

Gaudron S.M. \& Lucas M.C. 2006. First evidence of attraction of adult river lamprey in the migratory phase to larval odour. J. Fish Biol. 68: 640-644.

Goodwin C.E., Dick J.T.A., Rogowski D.L. \& Elwood R.W. 2008. Lamprey (Lampetra fluviatilis and Lampetra planeri) ammocoete habitat associations at regional, catchment and microhabitat scales in Northern Ireland. Ecol. Freshw. Fish 17: 542-553.

Hardisty M.W. \& Potter I.C. 1971. The biology of lampreys Vol. I. Academic Press, London, UK.

Hardisty M.W. 2006. Lampreys: life without jaws. Forrest Text, Ceredigion, UK.

Hiltunen E., Tolonen R., Kaski O. \& Oikarinen J. 2013. Nahkiainen-Perämeri, Tornio-Kokkola alue. Nahkiainen ennen, nyt ja tulevaisuudessa -hanke, Ii, Finland.

Holling C.S. (ed.) 1978. Adaptive Environmental Assessment and Management. Wiley, Chichester.

Huusko A., Vehanen T. \& Stickler M. 2013. Salmonid Habitats in Riverine Winter Conditions with Ice. In: Maddock I, Harby A, Kemp P. \& Wood P. (eds), Ecohydraulics: An Integrated Approach, Wiley-Blackwell, New Delhi, pp. 177-192.

Huusko A., Greenberg L., Stickler M., Linnansaari T., Nykänen M., Vehanen T., Koljonen S., Louhi P. \& Alfredsen K. 2007. Life in the ice line: The winter ecology of stream salmonids. River Res. Appl. 23: 469-491.

Jackson A. \& Moser M.L. 2012. Low-elevation dams are impediments to adult Pacific lamprey spawning migration in the Umatilla River, Oregon. N. Am. J. Fish. Man. 32: 548-556.

Jang M.H. \& Lucas M.C. 2005. Reproductive ecology of the river lamprey. J. Fish Biol. 66: 499-512. 
Kainua K. \& Valtonen T. 1980. Distribution and abundance of European river lamprey (Lampetra fluviatilis) larvae in three rivers running into Bothnian Bay, Finland. Can. J. Fish. Aquat. Sci. 37: 1960-1966.

Kemp P.S., Russon I.J., Vowles A.S. \& Lucas M.C. 2011. The influence of discharge and temperature on the ability of upstream migrant adult river lamprey (Lampetra fluviatilis) to pass experimental overshot and undershot weirs. River Res. Appl. 27: 488-498.

Laine A., Kamula R. \& Hooli J. 1998. Fish and lamprey passage in a combined Denil and vertical slot fishway. Fish. Man. Ecol. 5: 31-44.

Laukkanen E. 1984. Kalajoen kalataloudellinen tarkkailututkimus 1981-1982. Kokkolan vesipiirin vesitoimisto, Kokkola, Finland.

Lee D.S. 1989. Qualified laboratory assessment of larval lamprey substrate habitat selection. Great Lakes Fishery Comission, Research Completion Report, GLFC, Michigan.

Lind L. \& Nilsson C. 2014. River ice processes in channelized and restored streams and rivers. Abstract in 10th International Symposium on Ecohydraulics, Trondheim, Norway.

Lucas M.C., Bubb D.H., Jang M.-H., Ha K. \& Masters J.E.G. 2009. Availability of and access to critical habitats in regulated rivers: effects of low-head barriers on threatened lampreys. Freshwater Biol. 54: 621-634.

Maitland P.S. 2003. Ecology of river, brook and sea lamprey. Conserving Natura 2000 Rivers Ecology Series No. 5, English Nature, Peterborough, UK.

Masters J.E.G., Jang M.-H., Ha K., Bird P.D., Frear P.A. \& Lucas M.C. 2006. The commercial exploitation of a protected anadromous species, the river lamprey (Lampetra fluviatilis (L.)), in the tidal River Ouse, north-east England. Aquat. Conserv. 16: 77-92.

Mateus C.S., Rodríguez-Muñoz R., Quintella B.R., Alves M.J. \& Almeida P. 2012. Lampreys of the Iberian Peninsula: distribution, population status and conservation. Endanger. Species Res. 16: 183-198.

McMichael G.A., Rakowski C.L., James B.B. \& Lukas J.A. 2005. Estimated fall Chinook salmon survival to emergence in dewatered redds in a shallow side channel of the Columbia River. N. Am. J. Fish. Man. 25: 876-884.

Meckley T.D., Wagner C.M. \& Luehring M.A. 2012. Field evaluation of larval odor and mixtures of synthetic pheromone components for attracting migrating sea lampreys in rivers. J. Chem. Ecol. 38: 1062-1069.

Moursund R.A., Dauble D.D. \& Langeslay M.J. 2003. Turbine intake diversion screens: investigating effects on Pacific lamprey. Hydro Review 22: 40-46.

Moser M.A., Ocker P.A., Stuehrenberg L.C. \& Bjornn T.C. 2002. Passage efficiency of adult Pacific lampreys at hydropower dams on the Lower Columbia River, USA. Trans. Am. Fish. Soc. 131: 956-965.

Moser M.L., Keefer M.L., Pennington H.T., Ogden D.A. \& Simonson J.E. 2011. Development of Pacific lamprey fishways at a hydropower dam. Fish. Man. Ecol.18: 190-200.

Myllynen K., Ojutkangas E. \& Nikinmaa M. 1997. River water with high iron concentration and low $\mathrm{pH}$ causes mortality of lamprey roe and newly hatched larvae. Ecotox. Environ. Safe. 36: 43-48. 
Mäenpää E. 2002. Nahkiaisen toukkien elinalueiden kartoitukset ja tiheydet eräissä LänsiSuomen joissa. Alueelliset ympäristöjulkaisut 265: 1-48.

Mäenpää E., Myllynen K., Pakkala J., Aronsuu K. \& Koskenniemi E. 2001. Talvehtimisaikaisen veden laadun vaikutus sukukypsien nahkiaisten (Lampetra fluviatilis) fysiologiseen tilaan ja mädin hedelmöittymiseen. Länsi-Suomen ympäristökeskus, Kokkola, Finland.

Mäkelä H. \& Kokko H. (eds) 1990. Nahkiaiskantojen hoito. Vesi- ja ympäristöhallituksen monistesarja 208: 1-101.

Neeson T.M., Wiley M.J., Adlerstein S.A. \& Riolo R.L. 2011. River network structure shapes interannual feedbacks between adult sea lamprey migration and larval habitation. Ecol. Model. 222: 3181-3192.

Negishi J.N., Inoue M. \& Nunokawa M. 2002. Effects of channelisation on stream habitat in relation to a spate and flow refugia for macroinvertebrates in northern Japan. Freshwater Biol. 47: 1515-1529.

Nika N \& Virbickas T. 2010. Brown trout Salmo trutta redd superimposition by spawning Lampetra species in a lowland stream J. Fish Biol 77: 2358-2372.

Nyberg K., Vikström R. \& Pakkala J. 2002. Perhonjokeen istutettujen merkittyjen nahkiaisentoukkien tutkimukset vuosina 1995-1998. Alueelliset ympäristöjulkaisut 251: $1-50$.

Ojutkangas E., Aronen K. \& Laukkanen E. 1995. Distribution and abundance of river lamprey (Lampetra fluviatilis) ammocoetes in the regulated River Perhonjoki. Regul. River. 10: 239-245.

Palomäki R. \& Koskenniemi E. 1993. Effects of bottom freezing on macrozoobenthos in the regulated Lake Pyhäjärvi. Arch. Hydrobiol. 128: 73-90.

Persson E., Bieri M., Armin P. \& Schleiss A.J. 2014. Mitigation measures for fish habitat improvement in Alpine rivers affected by hydropower operations. Ecohydrology 7: 580-599.

Potter I.C. 1980. Ecology of larval and metamorphosing lampreys. Can. J. Fish. Aquat. Sci. 37: 1641-1657.

Prowse T.D. \& Culp J.M. 2003. Ice breakup: a neglected factor in river ecology. Can. J. Civil Eng. 30: 128-144.

Quintella B.R., Andrade N.O., Koed A. \& Almeida P.R. 2004. Behavioural patterns of sea lampreys' spawning migration through difficult passage areas, studied by electromyogram telemetry. J. Fish Biol. 65: 961-972.

Renaud C.B. 1997. Conservation status of Northern Hemisphere lampreys (Petromyzontidae). J. Appl. Ichthyol. 13: 143-148.

Ruhanen T. 198. Perhonjoen keskiosan järviryhmän säännöstelyn täydennyshakemus -virtaamaja vedenkorkeusselvitykset. Kokkolan vesi- ja ympäristöpiiri, Kokkola, Finland.

Russon I.J., Kemp P.S. \& Lucas M.C. 2011. Gauging weirs impede the upstream migration of adult river lamprey Lampetra fluviatilis. Fish. Man. Ecol. 18: 201-210.

Sarkki H. 2005. Perhonjoen hydrologiset selvitysvelvoitteet. Länsi-Suomen ympäristökeskus, Kokkola, Finland.

Savolainen M. \& Leiviskä P. 2008. Kalajoen vesistön tulvan-torjunnan toimintasuunnitelma. Pohjois-Pohjanmaan ympäristökeskuksen raportteja 2. Pohjois-Pohjanmaan ympäristökeskus: Kokkola, Finland. 
Silva S., Gooderham A., Forty M., Morland B. \& Lucas M.C. 2015. Eggdrift and hatching success in European river lamprey Lampetra fluviatilis: is egg deposition in gravel vital to spawning success? Aquat. Conserv. 25: 534-543.

Sjöberg K. 1980. Ecology of the European river lamprey (Lampetra fluviatilis) in Northern Sweden. Can. J. Fish. Aquat. Sci. 37: 1974-1980.

Sjöberg K. 2011. River lamprey Lampetra fluviatilis (L.) fishing in the area around the Baltic Sea. Journal of Northern Studies 5: 51-86.

Smith S.J. \& Marsden J.E. 2009. Factors Affecting Sea Lamprey Egg Survival. N. Am. J. Fish. Man. 29: 859-868.

Smith D.M., Welsh S.A. \& Turk P.J. 2011. Selection and preference of bentic habitat by small and large ammocoetes of the least brook lamprey (Lampetra aepyptera). Environ. Biol. Fish. 91: 421-428.

Smith D.M., Welsh S.A. \& Turk P.J. 2012. Available bentic habitat type may influence predation risk in larval lampreys. Ecol. Freshw. Fish 21: 160-163.

Sugiyama H. \& Goto A. 2002. Habitat selection by larvae of a fluvial lamprey, Letheron reissneri in a small stream and in an experimental aquarium. Ichthyol. Res. 49: 62-68.

Taverny G., Lasalle G., Ortusi I., Roqueplo C., Lepage M. \& Lambert P. 2012. From shallow to deep waters: habitats used by larval lampreys (genus Petromyzon and Lampetra) over a western European basin. Ecol. Freshw. Fish 21: 87-99.

Tuunainen P., Ikonen E. \& Auvinen H. 1980. Lampreys and lamprey fisheries in Finland. Can. J. Fish. Aquat. Sci. 37: 1953-1959.

Valtonen T. 1980. European river lamprey (Lampetra fluviatilis) fishing and lamprey populations in some rivers running into Bothnian Bay, Finland. Can. J. Fish. Aquat. Sci. 37: 1967-1973.

Vikström R. 2002. Nahkiaisen viljelyä ja viljelykokemuksia. Alueelliset ympäristöjulkaisut 252: $1-58$.

Vrieze L.A., Bjerselius R. \& Sorensen P.W. 2010. Importance of the olfactory sense to migratory sea lampreys petromyzon marinus seeking riverine spawning habitat. $J$. Fish Biol. 76: 949-964.

Vrieze L.A., Bergstedt R.A. \& Sorensen P.W. 2011. Olfactory-mediated stream-finding behavior of migratory adult sea lamprey (Petromyzon marinus). Can. J. Fish. Aquat. Sci. 68: 523-533.

Ward D.L., Clemens B.J., Clugston D., Jackson A.D., Moser M.L., Peery C. \& Statler D.P. 2012. Translocating Adult Pacific Lamprey within the Columbia River Basin: State of the Science. Fisheries 37: 351-361.

Weber C., Peter A. \& Zanini F. 2007. Spatio-temporal analysis of fish and their habitat: a case study on a highly degraded Swiss river system prior to extensive rehabilitation. Aquat. Sci. 69: 162-172.

Weber C., Nilsson C., Lind L., Alfredsen K.T. \& Polvi L.E. 2013. Winter Disturbances and Riverine Fish in Temperate and Cold Regions. BioScience 63: 199-210.

Yrjänä T. 1998. Efforts for In-stream Fish Habitat Restoration within the River Iijoki, Finland - Goals, Methods and Test Results. In: de Waal L., Large A., \& Wade M. (eds), Rehabilitation of Rivers: Principles and Implementation, John Wiley \& Sons Ltd., Sussex, pp. 239-250. 
Yrjänä T., van der Meer O., Riihimäki J. \& Sinisalmi T. 2002. Contributions of short-term flow regulation patterns to trout habitats in a boreal river. Boreal Environ. Res. 7: 7789. 


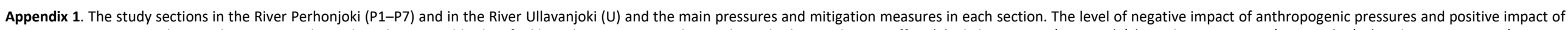

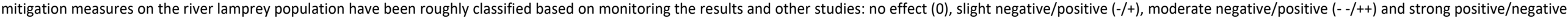

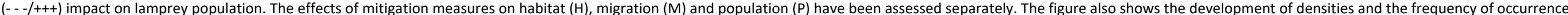
of lamprey larvae in the different sections and the number of upmigrating adult lampreys (N) and the index of adults starting wintering (Esc = escapement) in 1981-2010.
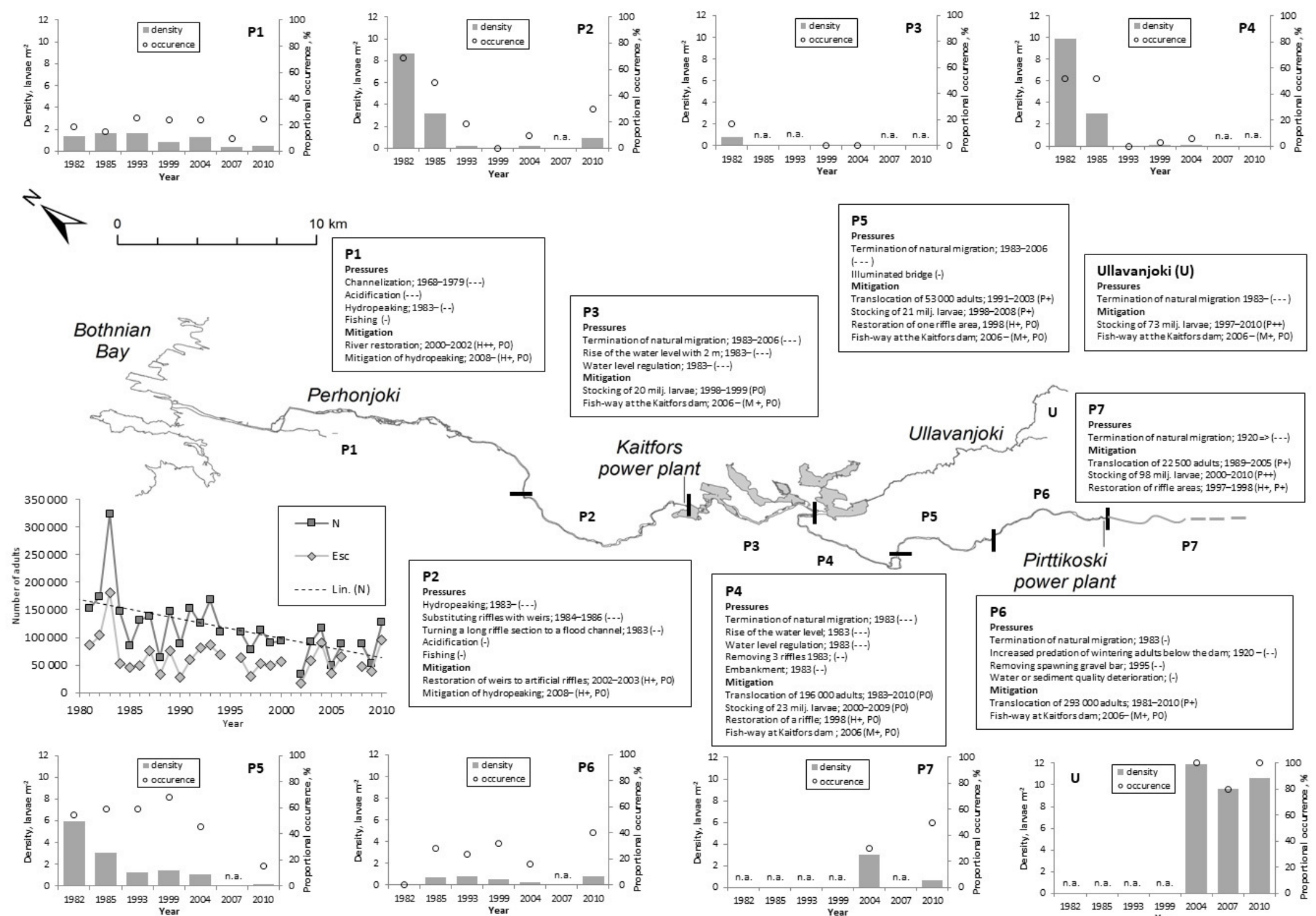

Pirttikoski

P4

Pressures
Termination of natural migration; $1983(--$. Rise of the water level; $1983(-.-)$ Water level regulation; 1983 Removing 3 riffles 1983;
Embankment; $1983(-)$ )

Mitigation Translocation of 196000 adults; 1983-2010(PO) Stocking of 23 mili. lavae; $2000-2009$ (PO)

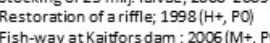

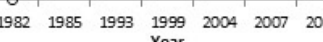

$198219851993 \quad 1999200420072010$

$\begin{array}{llllll}1982 & 1985 & 1993 & 1999 & 2004 & 2007 \\ 2010\end{array}$ 


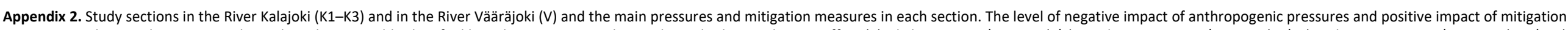

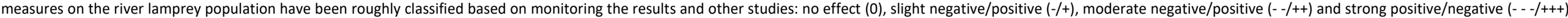

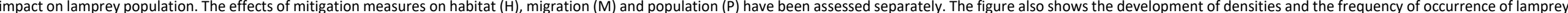
larvae in the different sections and the number of upmigrating adult lampreys $(\mathrm{N})$ and the index of adults starting wintering (Esc = escapement) in 1981-2010.

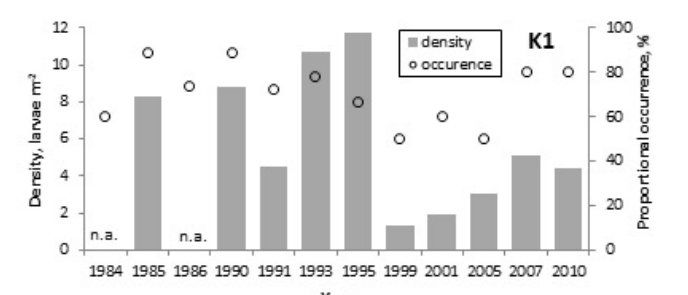

Year

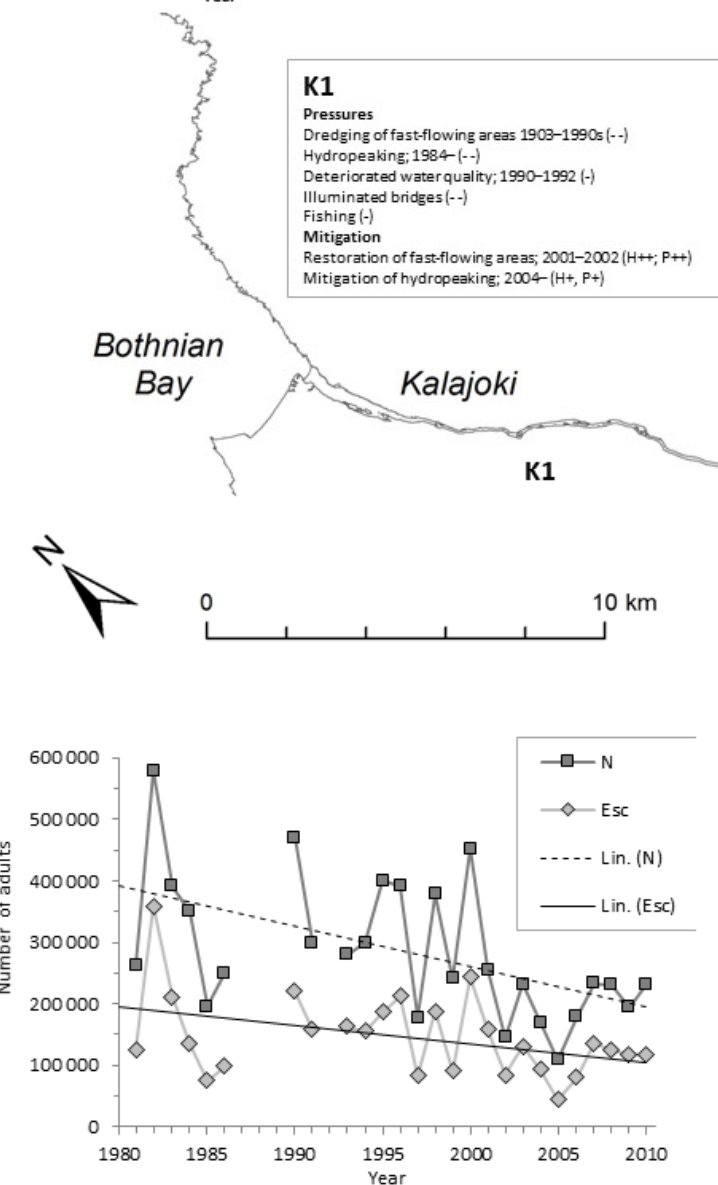

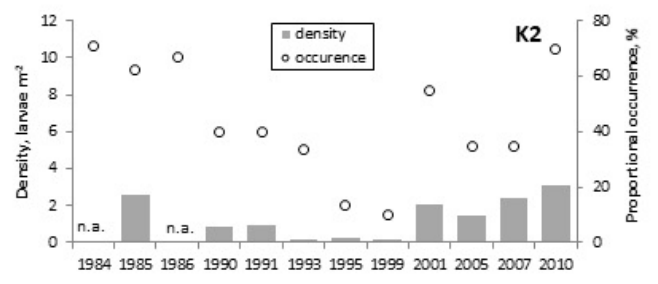

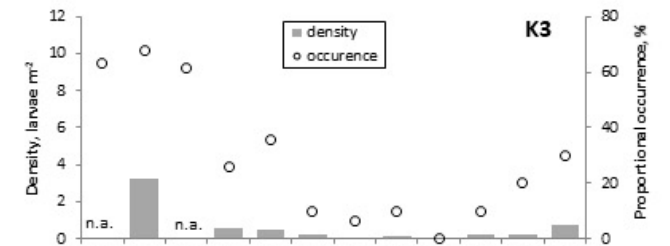

198419851986199019911993199519992001200520072010

\section{K2}

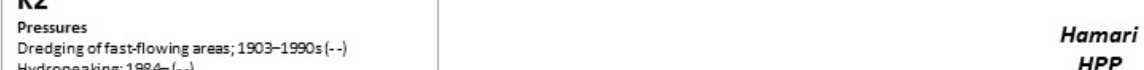

Hydropeaking, $1984-(--)$
Illuminated bridges $(--)$

Deteriorated water quality; 1990-1992 (--)
Fishing (-)

Mitigation
Restoration offast-flowing areas; $2001-2002(H+, P+H)$

Mitigation of hydropeaking; $2004-(\mathrm{H}+\mathrm{P}+)$

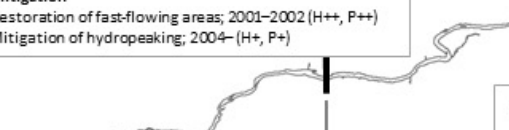

K3

K2

weir

Pressures
Dredging of fast-fllowing areas; $1903-1990$ s (-)
Dredging of slow-flowing areas; 1960 s- 1992 (-) Illuminated bridges (-)
Obstructed migration; $1992-1997(-$. Hydropeaking; $1984+(-.$.

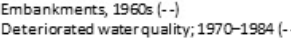
Substituting most of the riffles with block Fishing $(-)$
Mitigation

Vääräjoki Restoration of fast-flowing areas; $2002-2003(\mathrm{H}+\mathrm{P}+\mathrm{P})$ Mitigation of hydropeaking; $2004-(\mathrm{H}, \mathrm{Pt}+\mathrm{H}$ $(++, P+1$

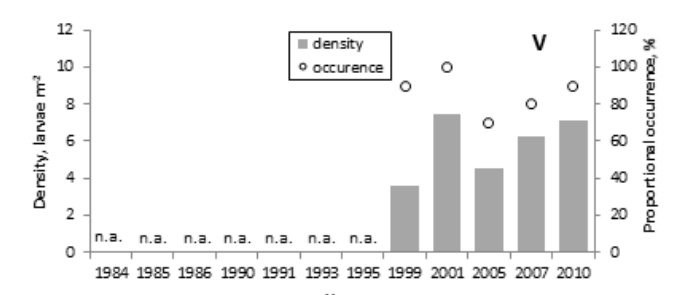

